\title{
Early Responses of Tobacco Suspension Cells to Rhizobacterial Elicitors of Induced Systemic Resistance
}

\author{
Leendert C. van Loon, ${ }^{1}$ Peter A. H. M. Bakker, ${ }^{1}$ Walter H. W. van der Heijdt, ${ }^{1}$ David Wendehenne, ${ }^{2}$ and \\ Alain Pugin ${ }^{2}$ \\ ${ }^{1}$ Plant-Microbe Interactions, Institute of Environmental Biology, Department of Biology, Faculty of Science, \\ Utrecht University, Padualaan 8, 3584 CH Utrecht, The Netherlands; ${ }^{2}$ Unité Mixte de Recherche INRA 1088/CNRS \\ 5184/Université de Bourgogne, Plante-Microbe-Environnement, 17 rue Sully, BP 86510, 21065 Dijon Cedex, France
}

Submitted 26 June 2008. Accepted 11 August 2008.

Colonization of roots by selected strains of fluorescent Pseudomonas spp. can trigger induced systemic resistance (ISR) against foliar pathogens in a plant species-specific manner. It has been suggested that early responses in cell suspension cultures in response to rhizobacterial elicitors, such as generation of active oxygen species (AOS) and extracellular medium alkalinization (MA), are linked to the development of ISR in whole plants. Perception of flagellin was demonstrated to elicit ISR in Arabidopsis, and bacterial lipopolysaccharides (LPS) have been shown to elicit several defense responses and to act as bacterial determinants of ISR in various plant species. In the present study, the LPS-containing cell walls, the pyoverdine siderophores, and the flagella of Pseudomonas putida WCS358, $P$. fluorescens WCS374, and $P$. fluorescens WCS417, which are all known to act as elicitors of ISR in selected plant species, were tested for their effects on the production of AOS, MA, elevation of cytoplasmic $\mathrm{Ca}^{2+}$ $\left(\left[\mathrm{Ca}^{2+}\right]_{\text {cyt }}\right)$, and defense-related gene expression in tobacco suspension cells. The LPS of all three strains, the siderophore of WCS374, and the flagella of WCS358 induced a single, transient, early burst of AOS, whereas the siderophores of WCS358 and WCS417 and the flagella of WCS374 and WCS417 did not. None of the compounds caused cell death. Once stimulated by the active compounds, the cells became refractory to further stimulation by any of the active elicitors, but not to the elicitor cryptogein from the oomycete Phytophthora cryptogea, indicating that signaling upon perception of the different rhizobacterial compounds rapidly converges into a common response pathway. Of all compounds tested, only the siderophores of WCS358 and WCS417 did not induce MA; the flagella of WCS374 and WCS417, although not active as elicitors of AOS, did induce MA. These results were corroborated by using preparations from relevant bacterial mutants. The active rhizobacterial elicitors led to a rapid increase in $\left[\mathrm{Ca}^{2+}\right]_{\mathrm{cyt}}$, peaking at $6 \mathrm{~min}$, whereas the inactive siderophores of WCS358 and WCS417 elicited a single spike at $1 \mathrm{~min}$. Elicitation of the cells by cell-wall LPS of WCS358 or the siderophore of WCS374 induced a weak, transient expression of several defense-related genes, including $P A L$ and $G S T$. The spectrum of early responses of the suspension cells was not matched by the expression of ISR in whole tobacco plants against Erwinia carotovora pv. carotovora. Of the live bacterial strains, only WCS358 elicited significant ISR, but application of the LPS or the

Corresponding author : L. C. van Loon; e-mail: L.C.vanloon@uu.nl siderophore of all three strains also elicited ISR. Notably, the absence of elicitation of AOS and MA in suspensioncultured cells but induction of ISR in whole plants by the siderophore of WCS358, which was lost upon treatment with the siderophore-minus mutant of WCS358, indicates that the early responses in suspension cells are not predictive of the ability to induce ISR in whole plants. Possible explanations for these discrepancies are discussed.

Plant roots support large populations of soil bacteria, notably of the genus Pseudomonas (Lugtenberg et al. 2001). These rhizosphere bacteria derive nutrients from root cell exudates and lysates and, in return, can promote plant growth and antagonize soilborne plant pathogens through multiple mechanisms (Handelsman and Stabb 1996; Van Loon 2007). In addition, specific bacterial strains can induce a systemic protection against both soilborne and foliar pathogens, a phenomenon known as induced systemic resistance (ISR) (Van Loon and Bakker 2005). Rhizobacteria-mediated ISR is independent of salicylic acid (SA) but requires jasmonate (JA) and ethylene signaling in the plant (Pieterse et al. 1998). This type of induced resistance confers priming of defense reactions in response to subsequent challenge with, particularly, necrotizing pathogens (Ton et al. 2002). ISR has been extensively studied in Arabidopsis but has also been convincingly demonstrated in salicylate nonaccumulating $\mathrm{NahG}$ tobacco and tomato plants that are unable to express pathogen-inducible, SA-dependent systemic acquired resistance (SAR). In contrast to SAR, ISR is not commonly associated with an accumulation of pathogenesis-related (PR) proteins, even though varying changes at the transcriptional level in reaction to several resistance-inducing rhizobacteria have been documented (Van Loon 2007).

For a number of resistance-inducing bacterial strains, the ISR-eliciting compounds have been identified and shown to comprise the cell wall outer membrane lipopolysaccharide (LPS), iron-chelating siderophores, flagella, antibiotics, quorum-sensing $\mathrm{N}$-acylhomoserine lactones, and volatile compounds, such as 2,3-butanediol (Van Loon 2007). Bacterial LPS and flagella have been demonstrated to act as elicitors of innate immunity in animals and to function likewise as pathogen-associated molecular patterns (PAMPs) that are perceived by plants (Nürnberger et al. 2004). Recognition of these PAMPs leads to the activation of inducible plant defense responses that may confer nonhost resistance to nonhost plants and activate basal resistance and reduce disease severity in host plants (Desender et al. 2007; He et al. 2007; Jones and Dangl 2006; Li et al. 2005; Nürnberger and Lipka 2005). 
Purified LPS from the bacterial leaf pathogen Xanthomonas campestris was shown to induce defense-related gene expression in Brassica campestris and to prevent the hypersensitive response in the resistant host Capsicum anuum in association with a more rapid induction of antimicrobial hydroxycinnamoyltyramine conjugates upon challenge by $X$. axonopodis (Erbs and Newman 2003). Similarly, infiltration of LPS from the bacterial wilt pathogen Ralstonia solanacearum or from the nonpathogens Escherichia coli and Serratia marcescens reduced hypersensitive tissue collapse when the same leaf area was subsequently infiltrated with live pathogen (Graham et al. 1977).

Protection of tobacco against the black shank-causing oomycete Phytophthora nicotianae by pretreatment of the leaves with LPS from the nonpathogenic bacterial endophyte Burkholderia cepacia was associated with an accumulation of uncharacterized PR proteins (Coventry and Dubery 2001) and phosphorylation of an ERK-like mitogen-activated protein (MAP) kinase (Piater et al. 2004). In tobacco cell suspensions, the LPS induced a rapid influx of $\mathrm{Ca}^{2+}$ into the cytoplasm of aequorintransformed cells, an oxidative burst concomitant with the production of reactive oxygen and nitrogen species, alkalinization of the extracellular culture medium (Gerber et al. 2004), and rapid phosphorylation of several proteins (Gerber and Dubery 2004) involved in various signaling and regulatory mechanisms (Gerber et al. 2006), as well as alterations in the expression of several genes (Sanabria and Dubery 2006). In Arabidopsis plants, LPS from either pathogenic or nonpathogenic bacteria induced several defense-related genes both locally and, to a much lesser extent, systemically, associated with the induction of a rapid burst of nitric oxide (NO) in cultured cells (Zeidler et al. 2004). In animals, the action of bacterial LPS is mediated by Toll-like receptors (Yang et al. 1998); however, receptors in plants have not been identified yet (Newman et al. 2007).

The mechanism by which flagella activate basal resistance responses is better understood. Conserved peptides within the major flagellar protein, flagellin, are perceived by the Toll-like receptor-like kinase FLS2 in Arabidopsis (Gomez-Gomez et al. 2001) and a presumably similar receptor in tomato (Robatzek et al. 2007). In Arabidopsis, it has been shown that flagellin perception is transduced through a MAP kinase cascade and WRKY transcription factors (Asai et al. 2002) to give rise to an enhanced resistance against invasion by the bacterial leaf pathogen Pseudomonas syringae pv. tomato, which was associated with callose deposition and activation of $P R$ genes (Gomez-Gomez et al. 1999). Cell cultures of several species, including tobacco, reacted to bacterial flagellins through the conserved peptide flg22 with a rapid alkalinization of the culture medium (Felix et al. 1999). In tobacco BY-2 cells, flagellins of nonhost pathogens induced an oxidative burst accompanied by cell death, whereas the flagellin of the host pathogen $P$. syringae pv. tabaci did not (Taguchi et al. 2003a), but did in nonhost tomato cells (Taguchi et al. 2003b). These differences appeared to be due to post-translational modifications of the flagellin (Taguchi et al. 2003b).

Iron is a limiting nutrient for both plant and microbial growth (Robin et al. 2006). Disease-suppressing rhizobacteria can directly antagonize soilborne pathogens by competition for iron through the release and specific uptake of iron-chelating siderophores in the rhizosphere (Höfte 1993). However, bacterial siderophores can also be perceived by plants and induce systemic resistance (Bakker et al. 2007); for example, as shown by the lack of systemic protection of tobacco against black root rot by a mutant of $P$. fluorescens $\mathrm{CHA} 0$ lacking the ability to produce the pseudobactin siderophore (Maurhofer et al. 1994). Bacterial siderophores can influence plant iron metabolism as well (Fett et al. 1998), but a relationship between iron nutritional status and induced resistance is unclear.
All rhizobacterial Pseudomonas spp. and strains possess LPS and flagella and produce siderophores under iron-limiting conditions. Yet their capacity to induce systemic resistance is strongly plant species dependent. Of three well-characterized strains, P. fluorescens WCS417 has been demonstrated to induce resistance in Arabidopsis, bean, carnation, radish, and tomato but not in Eucalyptus spp. or rice (Ran et al. 2005; Van Loon 2007). Compared with live bacterial cells, in Arabidopsis, cell walls of its rifampicin-resistant derivative WCS417 $r$ induced a reduced but still significant protection against $P$. syringae pv. tomato, whereas cell walls of a mutant of WCS417r that lacked the O-antigenic side chain of the LPS were fully ineffective (Van Wees et al. 1997). Thus, LPS contributes to the elicitation of ISR in Arabidopsis by WCS417r, but other factors must also be involved. In contrast to WCS417, P. fluorescens WCS374 is effective in rice, as it is in radish, but not in Arabidopsis. In radish, both its LPS and its pseudobactin siderophore have been implicated in eliciting ISR (Leeman et al. 1995, 1996). P. putida WCS358 induces resistance in Arabidopsis, bean, and tomato but not in carnation, radish, or rice. In Arabidopsis, the LPS, flagella, and the siderophore all triggered ISR whereas, in tomato and bean, the LPS and the siderophore were effective but flagella were not (Meziane et al. 2005). Thus, these three bacterial components were differentially active in these plant species. These differences are likely to be the result of different structures of the elicitors. The structure of LPS varies between bacterial strains, with most of the structural heterogeneity residing in the $\mathrm{O}$-antigenic polysaccharide side chain (Lerouge and Vanderleyden 2001). Similarly, flagellin gene sequence variations and post-translational modifications have been observed in the genus Pseudomonas (Bellingham et al. 2001; Taguchi et al. 2003b). Siderophores have highly strain-specific peptide structures to enable specific uptake of Fe-siderophore complexes (Visca et al. 2007). On the other hand, plant receptors can vary in their specificity to recognize bacterial elicitors (e.g., as evidenced from the different structural requirements for the perception of flagellin by Arabidopsis and tomato) (Robatzek et al. 2007).

The differential specificities of the rhizobacterial elicitors prompted us to initiate a study to compare early responses thought to represent initial signaling steps in the elicitation of ISR by comparing LPS-containing cell walls, flagella, and pseudobactin siderophores of strains WCS417, WCS358, and WCS374 in a single, well-characterized plant system (i.e., suspension-cultured cells of tobacco cv. Xanthi). These cells have been characterized extensively for their early responses to elicitors such as cryptogein from the oomycete Phytophthora cryptogea (Garcia-Brugger et al. 2006), which include production of active oxygen species (AOS), extracellular medium alkalinization, $\mathrm{Ca}^{2+}$ influx and cytoplasmic $\mathrm{Ca}^{2+}\left(\left[\mathrm{Ca}^{2+}\right]_{\text {cyt }}\right)$ elevation, cell death, and early gene expression. These responses were examined and related to the effectiveness of the three rhizobacterial strains to induce systemic resistance in intact tobacco plants against the bacterial soft rot pathogen Erwinia carotovora.

\section{RESULTS}

\section{Generation of active oxygen species.}

Pseudomonas fluorescens WCS417 has been demonstrated to induce systemic resistance in several plant species, including Arabidopsis. The O-antigenic side chain of the LPS is one of the determinants involved, but the nature of other elicitors of this bacterium has not been investigated. Addition of cell walls of WCS417 to tobacco cell suspensions provoked an almost immediate and transient burst of AOS that attained a maximum after approximately $10 \mathrm{~min}$ and then returned to control level within 1 
h (Fig. 1A). No further increase occurred at longer times (data not shown). Re-addition of cell walls after $60 \mathrm{~min}$ did not lead to a renewed burst, indicating that the cells had become refractory to repeated stimulation by the cell walls. In contrast, when, instead of the bacterial cell walls, the elicitor cryptogein was added at $60 \mathrm{~min}$, a strong production of AOS started after approximately $10 \mathrm{~min}$, reached a peak around $30 \mathrm{~min}$ and remained elevated for the duration of the experiment (Fig. 1A). This oxidative burst was comparable in timing and magnitude with the cryptogein-induced burst of AOS produced by tobacco cells that had not been exposed previously to bacterial cell walls (Fig. 1B). Thus, the tobacco cells were fully capable of reacting to cryptogein after prior stimulation with cell walls of strain WCS417. When the cells were first stimulated with cryptogein and then bacterial cell walls were added at $60 \mathrm{~min}$, no effect of the latter was evident, indicating that, once stimulated by cryptogein, the cells remained activated and were no longer responsive to the bacterial cell walls (Fig. 1B).

The pseudobactin siderophore of WCS417 did not lead to the production of AOS in the tobacco cells, and the effect of the flagella of this strain was negligible (Table 1), indicating that the tobacco cells reacted by an oxidative burst only in response to the cell walls of WCS417. Indeed, cell walls prepared from a flagella-minus $\left(\mathrm{FL}^{-}\right)$mutant of WCS417 were as active as those of the wild-type strain (Table 1).

Of $P$. putida WCS358, the cell walls, siderophore, and flagella have all been shown to induce systemic resistance in Arabidop-
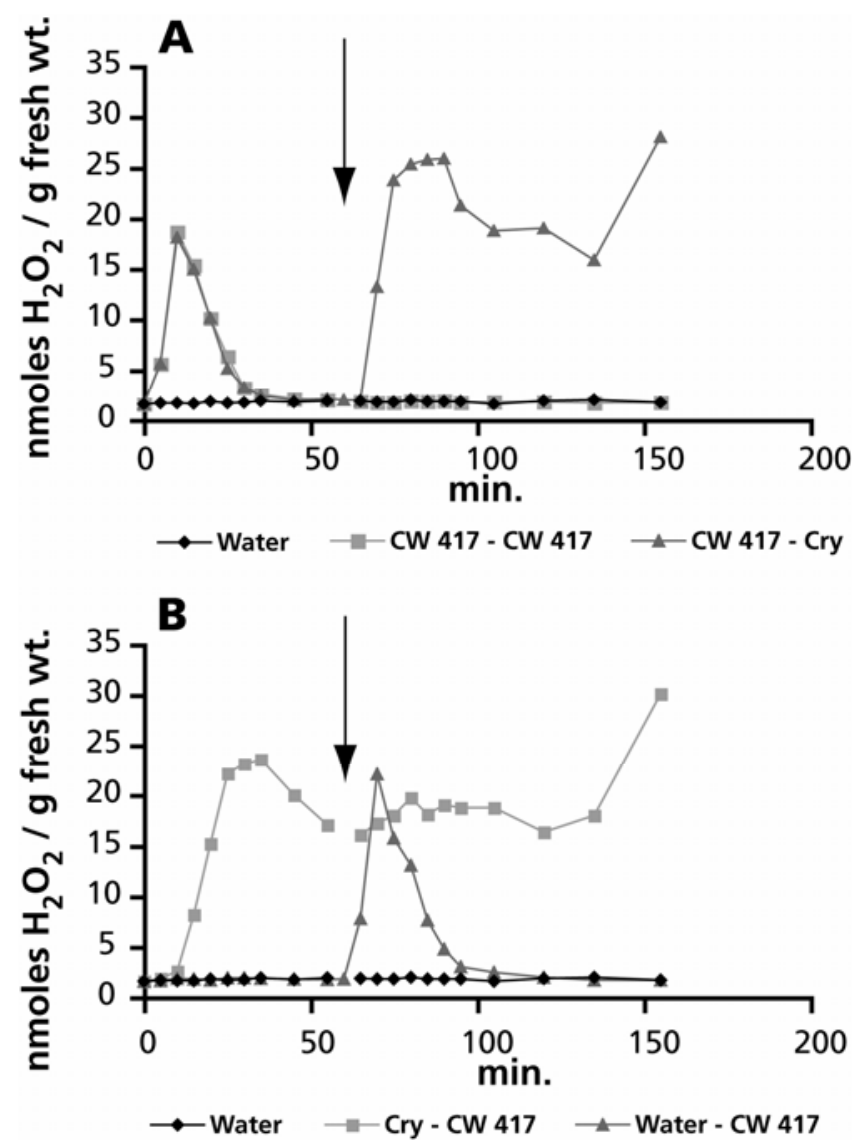

Fig. 1. Production of active oxygen species by tobacco cv. Xanthi cell suspensions in response to cell walls $\left(10 \mu \mathrm{g} \mathrm{ml}^{-1}\right)$ from Pseudomonas fluorescens WCS417 (CW 417) or cryptogein $(25 \mathrm{nM})$. A, Water control ( ), CW 417 followed at $60 \mathrm{~min}$ (arrow) by re-addition of CW 417 (घ), or CW 417 followed by addition of cryptogein at $60 \min (\mathbf{\Delta})$. B, water control ( ), cryptogein followed at $60 \mathrm{~min}$ (arrow) by addition of CW 417 (匹), or addition of $\mathrm{CW} 417$ at $60 \mathrm{~min}$ to a water control $(\boldsymbol{\Delta})$. The data are from representative experiments out of a total of 13 .
Table 1. Production of active oxygen species by tobacco cv. Xanthi cells in response to components of Pseudomonas putida WCS358, P. fluorescens WCS374, and P. fluorescens WCS417 and their mutants lacking the $\mathrm{O}$-antigenic side chain of the cell wall lipopolysaccharide $\left(\mathrm{OA}^{-}\right)$, the flagella $\left(\mathrm{FL}^{-}\right)$, or the pseudobactin siderophore $\left(\mathrm{PB}^{-}\right)^{\mathrm{a}}$

\begin{tabular}{|c|c|c|c|}
\hline \multirow[b]{2}{*}{$\begin{array}{l}\text { Bacterial } \\
\text { strain }\end{array}$} & \multicolumn{3}{|c|}{ Compound } \\
\hline & $\begin{array}{c}\text { Cell walls } \\
\left(10 \mu \mathrm{g} \mathrm{ml}^{-1}\right)\end{array}$ & $\begin{array}{c}\text { Flagella } \\
\left(1 \mu \mathrm{g} \mathrm{ml}^{-1}\right)\end{array}$ & $\begin{array}{c}\text { Pseudobactin } \\
\left(10 \mu \mathrm{g} \mathrm{ml}^{-1}\right)\end{array}$ \\
\hline \multicolumn{4}{|l|}{ WCS358 } \\
\hline WT & 19.0 & 8.5 & 0 \\
\hline $\mathrm{OA}^{-}$ & 18.3 & - & - \\
\hline $\mathrm{FL}^{-}$ & 19.7 & - & - \\
\hline $\mathrm{PB}^{-}$ & 0.1 & - & - \\
\hline \multicolumn{4}{|l|}{ WCS374 } \\
\hline WT & 21.0 & ns & 11.1 \\
\hline $\mathrm{OA}^{-}$ & 21.9 & - & - \\
\hline $\mathrm{FL}^{-}$ & 22.3 & - & - \\
\hline $\mathrm{PB}^{-}$ & 22.0 & - & - \\
\hline \multicolumn{4}{|l|}{ WCS417 } \\
\hline WT & 20.6 & ns & 0 \\
\hline $\mathrm{OA}^{-}$ & 6.4 & - & - \\
\hline $\mathrm{FL}^{-}$ & 18.2 & - & - \\
\hline $\mathrm{PB}^{-}$ & 18.9 & - & - \\
\hline
\end{tabular}

${ }^{\text {a }}$ Maximum production rates reached at 10 to 15 min after addition of the compounds are indicated and expressed as nmol $\mathrm{H}_{2} \mathrm{O}_{2}$ per gram fresh weight of cells; WT $=$ wild type, $\mathrm{ns}=$ nonsignificant, and $-=$ not determined.
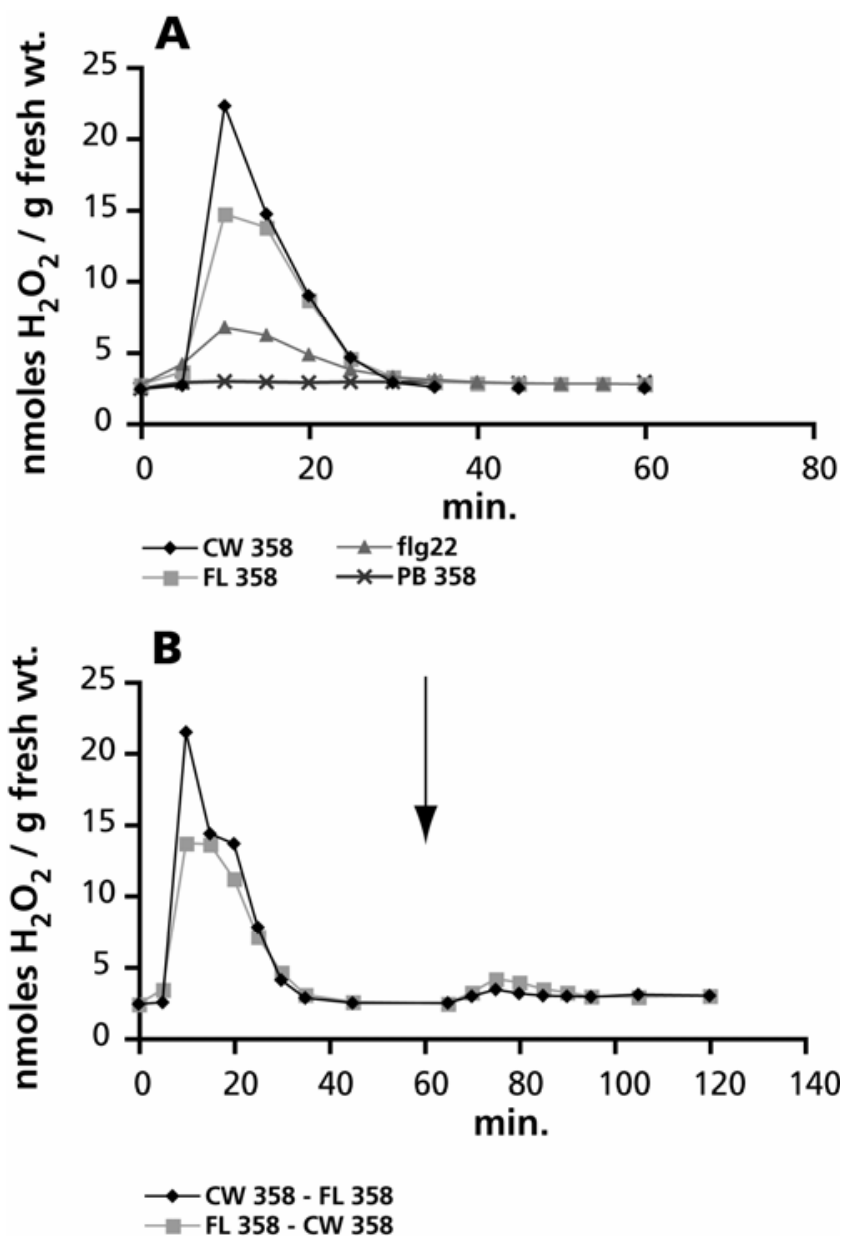

Fig. 2. Production of active oxygen species by tobacco cv. Xanthi cell suspensions in response to components of Pseudomonas putida WCS358 or the peptide flg22. A, Cell walls $\left(10 \mu \mathrm{g} \mathrm{m}^{-1}\right)(\mathrm{CW} 358)(\diamond)$, purified flagella from WCS $358\left(1 \mu \mathrm{g} \mathrm{ml}^{-1}\right)($ FL 358) (ם), $100 \mathrm{nM}$ flg22 (A), or purified pseudobactin $\left(10 \mu \mathrm{g} \mathrm{m} \mathrm{m}^{-1}\right.$ ) (PB 358) (×). B, CW 358 followed at 60 min (arrow) by addition of FL $358(\diamond)$ or FL 358 followed by addition of $\mathrm{CW} 358$ at $60 \mathrm{~min}(\boldsymbol{\square})$. The data are from representative experiments out of a total of 17 . 
sis. When added to the tobacco cells, both the cell walls and the flagella induced an oxidative burst similar to the one induced by WCS417 cell walls. Moreover, the burst resembled the one induced by the well-characterized flg22 elicitor peptide, except that the ones induced by the bacterial compounds were much stronger (Fig. 2A). The siderophore of WCS358 proved inactive, like the siderophore of WCS417 (Table 1).

Because the bacterial cell wall preparations were derived from killed bacterial cells containing flagella, it was considered that the effect of the WCS358 cell walls might be caused by the flagella, which provoke a comparable response. This notion was supported by our observations that treatment of the tobacco cells with flagella $60 \mathrm{~min}$ after the addition of the cell walls caused only a slight oxidative burst, as was also the case upon restimulation by cell walls after initial stimulation by flagella (Fig. 2B). However, cell walls of an $\mathrm{FL}^{-}$mutant of WCS358 were as active as those of the wild-type strain, reaching the same peak value after $10 \mathrm{~min}$. The same applied to cell walls of a mutant lacking the $\mathrm{O}$-antigenic side chain of the cell wall LPS (Table 1). These results suggest that WCS358 cell walls and flagella can independently provoke the same response in tobacco suspension cells.
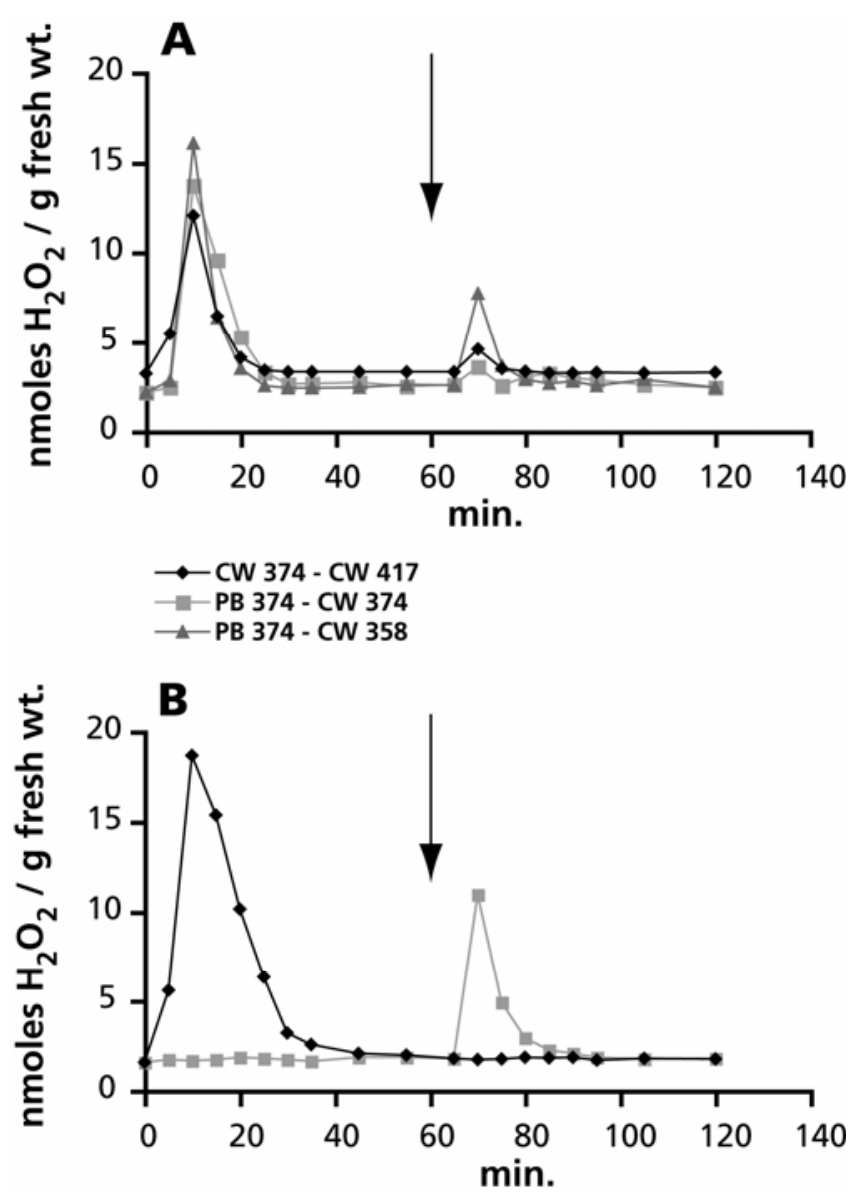

$\longrightarrow$ - CW 417 - PB 374

-Water - PB 374

Fig. 3. Production of active oxygen species by tobacco cv. Xanthi cell suspensions in response to components of Pseudomonas fluorescens WCS374 prior to or following cell wall preparations of the three strains. A, Cell walls $\left(10 \mu \mathrm{g} \mathrm{ml}^{-1}\right)(\mathrm{CW} 374)$ followed at $60 \mathrm{~min}$ (arrow) by addition of CW $417(\diamond)$, pseudobactin $\left(10 \mu \mathrm{g} \mathrm{ml}^{-1}\right.$ ) (PB 374) followed by addition of CW 374 at $60 \mathrm{~min}(\mathbf{\square})$, or PB 374 followed by CW 358 at $60 \mathrm{~min}(\mathbf{\Delta})$. B, CW 417 followed at $60 \mathrm{~min}$ (arrow) by addition of PB $374(\bullet)$ or addition of PB 374 at $60 \mathrm{~min}$ to water control (ם). The data are from representative experiments out of a total of 19 .
P. fluorescens WCS374 does not commonly induce systemic resistance in Arabidopsis but does so in radish, with both its cell walls and pseudobactin siderophore acting as inducing determinants. The tobacco cells reacted to WCS374 cell walls similarly as to the cell walls of WCS417 and WCS358 (Fig. $3 \mathrm{~A})$. To determine whether the response to the cell walls of WCS374 would make the tobacco cells fully refractory not only to the same preparation but also to the cell walls of the other bacterial strains, the cells were supplemented with those at $60 \mathrm{~min}$. As shown in Figure 3A for cell walls of WCS417, a small oxidative burst ensued $10 \mathrm{~min}$ later, indicating that the cells could be weakly restimulated by cell walls of another strain. The same result was obtained with cell walls of WCS358, whereas a second burst upon readdition of cell walls of WCS374 was fully suppressed (data not shown).

Contrary to the siderophores of WCS417 and WCS358, the pseudobactin siderophore of WCS374 provoked an oxidative burst with kinetics similar to the one induced by cell walls (Fig. 3A). The reaction to this siderophore caused almost complete refractoriness to additional stimulation by cell walls of WCS374 but only partial refractoriness to cell walls of the other strains (Fig. 3A, shown for WCS358 only). Thus, the siderophore and cell wall preparations seemed to largely but not completely activate the same pathway leading to the production of AOS. However, when the tobacco cells were first treated with cell walls of WCS417 and, after $60 \mathrm{~min}$, the siderophore of WCS374 was added, no restimulation was evident (Fig. 3B), suggesting that prior stimulation by cell walls suppresses the reaction to the siderophore. The refractoriness of the cells was diminished when the addition of the second stimulus was postponed. For instance, upon readdition of the same stimulus after $120 \mathrm{~min}$, an oxidative burst with a peak value of approximately $15 \%$ of the first one ensued, indicating that the cells become responsive again with time (data not shown). Flagellar preparations of WCS374 did not cause a significant induction of AOS in the tobacco cells (Table 1).

The active cell wall preparations of WCS417, WCS358, and WCS374 and the pseudobactin siderophore of WCS374 all showed similar dose-response characteristics, as exemplified for the siderophore in Figure 4. A minimum dose of $1 \mu \mathrm{g} / \mathrm{ml}$ was required to cause a significant increase in AOS, and the response was leveling off above $10 \mu \mathrm{g} / \mathrm{ml}$. As shown in Figure $5 \mathrm{~A}$ for the cell walls of WCS358, the oxidative burst was blocked by the general protein kinase inhibitor staurosporine, by the $\mathrm{Ca}^{2+}$ chelator EGTA as well as the inhibitor of plasma membrane $\mathrm{Ca}^{2+}$-permeable channels lanthanum $\left(\mathrm{LaCl}_{3}\right)$, and by the NADPH oxidase inhibitor DPI, indicating requirements for phosphorylation events, $\mathrm{Ca}^{2+}$ influx, and the action of NADPH oxidase, similar to the characteristics of the oxidative burst provoked by cryptogein (Pugin et al. 1997).

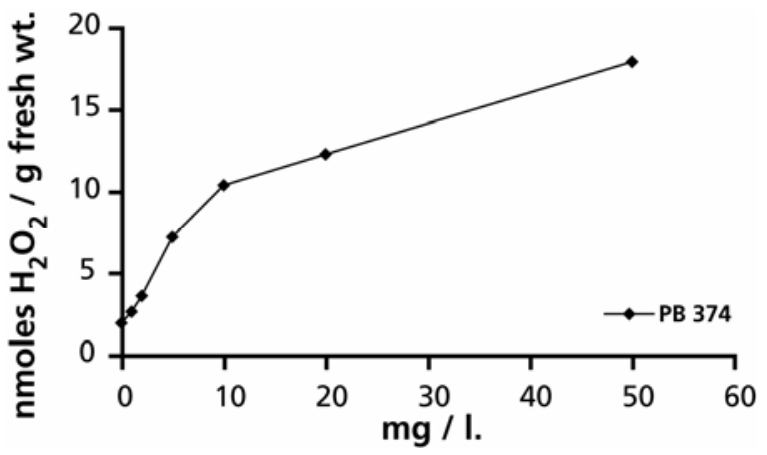

Fig. 4. Concentration dependency of the production of active oxygen species by tobacco cv. Xanthi cell suspensions in response to PB 374. The data are from representative experiments out of a total of four. 
To compare the relevance of the presence of the O-antigenic side chain of the bacterial LPS in the cell walls, of the flagella, and of the pseudobactin siderophore for the induction of the oxidative burst by the three types of preparations, the compounds from relevant bacterial mutants of the three strains were tested. Compared with the average peak value of 11.1 nmoles of $\mathrm{H}_{2} \mathrm{O}_{2}$ per gram fresh weight of tobacco cells for the siderophore of WCS374 (at $10 \mu \mathrm{g} \mathrm{ml}^{-1}$ ), and of 8.5 for the flagella of WCS358 (at $1 \mu \mathrm{g} \mathrm{ml}^{-1}$ ), cell wall preparations at $10 \mu \mathrm{g}$ $\mathrm{ml}^{-1}$ were, on average, twice as active (Table 1). Cell walls of all $\mathrm{FL}^{-}$mutants were as active as those of the wild-type strains. Those from the mutant of WCS417 lacking the O-antigenic side chain ( $\mathrm{OA}^{-}$mutant) had lost two-thirds of their inducing capacity, indicating that, for this strain, the O-antigenic side chain contributes greatly to the induction of the oxidative burst. In contrast, cell walls of the $\mathrm{OA}^{-}$mutants of WCS358 and WCS374 were as active as those of their wild types (Table 1).

The siderophores are secreted compounds and, in WCS417 and WCS358, did not contribute to the induction of AOS; therefore, it was expected that cell walls of the siderophoreminus $\left(\mathrm{PB}^{-}\right)$mutants would show the same inducing activities as their wild types. This was the case for WCS417 and WCS374 but not for WCS358, whose cell walls had lost all activity (Table 1). Presumably, the $\mathrm{PB}^{-}$phenotype of this mutant is related to an as-yet-uncharacterized alteration in cell wall properties.

None of the bacterial compounds induced death of the tobacco suspension cells. After $24 \mathrm{~h}$, the percentage of dead cells amounted to $6 \pm 1 \%$, comparable with the water controls. In contrast, of cells treated with $25 \mathrm{nM}$ cryptogein, approximately $50 \%$ had succumbed (data not shown).

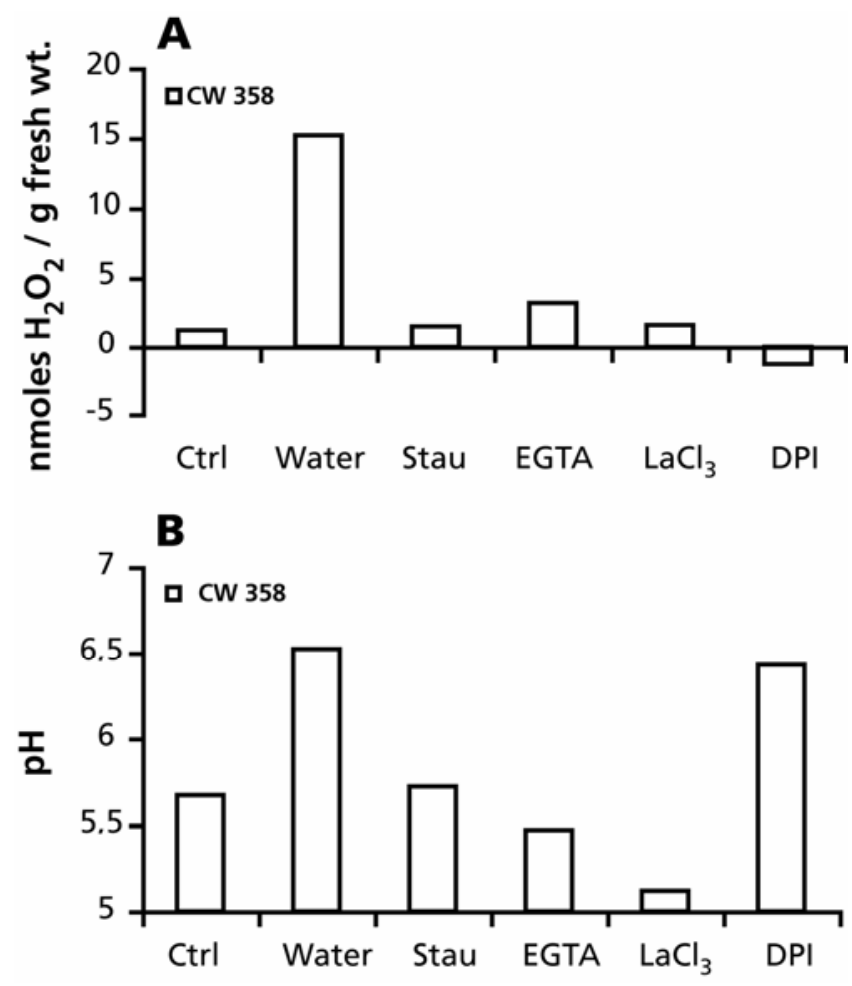

Fig. 5. Effects of inhibitors on $\mathbf{A}$, the production of active oxygen species and $\mathbf{B}$, medium alkalinization by tobacco cv. Xanthi cell suspensions in response to $\mathrm{CW} 358\left(10 \mu \mathrm{g} \mathrm{ml}^{-1}\right)$. Stau $=5 \mu \mathrm{M}$ staurosporine, an inhibitor of protein phosphorylation; EGTA (2 mM), a Ca-chelator; $\mathrm{LaCl}_{3}(1 \mathrm{mM})$, a competitive inhibitor of $\mathrm{Ca}^{2+}$ fluxes; DPI $=10 \mu \mathrm{M}$ diphenyleneiodonium, an inhibitor of plasma membrane-bound NADPH oxidase. The data are from representative experiments out of a total of four.

\section{Extracellular medium alkalinization.}

Those bacterial compounds that induced an oxidative burst were also active in generating a rapid alkalinization of the extracellular medium (Table 2). However, cell walls of the WCS417 $\mathrm{OA}^{-}$mutant were almost as active and those of the WCS358 $\mathrm{PB}^{-}$mutant were approximately half so. Moreover, flagella of WCS417 and WCS374 were also active, be it slightly and substantially less so, respectively, than flagella of WCS358 (Table 2). As exemplified in Figure 6A for the elicitors from WCS358, the cell walls caused a transient increase in extracellular $\mathrm{pH}$ of more than one unit within $10 \mathrm{~min}$, with a peak between 10 and $20 \mathrm{~min}$, followed by a gradual subsidence over the next hour, whereas the siderophore was totally inactive. In contrast, the flagella of WCS358 and the siderophore of WCS374 induced a response similar to cell walls and very different from that to cryptogein. The latter started to raise the extracellular $\mathrm{pH}$ only after 15 to $20 \mathrm{~min}$, and a plateau was reached after 20 to $40 \mathrm{~min}$ (Fig. 6A).

In contrast to the refractoriness of the tobacco cells to restimulation of an oxidative burst, the cells were able to almost fully re-alkalinize the medium upon repeated stimulation (Fig. $6 \mathrm{~B})$, even when the same elicitor was re-added after $40 \mathrm{~min}$ (data not shown). It made almost no difference whether the cells were restimulated by the same or heterologous cell walls or the siderophore of WCS374 (Figs. 6B and 7). In contrast, restimulation of the tobacco cells by flagella did reduce the second alkalinization response, as exemplified by those of WCS358 shown in Figure 7.

The increase in extracellular $\mathrm{pH}$ was fully blocked by staurosporine but not by DPI, indicating that medium alkalinization is dependent on phosphorylation events but independent of the oxidative burst. The $\mathrm{Ca}^{2+}$-influx inhibitors EGTA and $\mathrm{LaCl}_{3}$ even caused medium acidification (Fig. 5B). These effects were again similar to the action of these inhibitors on cryptogein-stimulated cells (Tavernier et al. 1995).

Increase in $\left[\mathrm{Ca}^{2+}\right]_{\mathrm{cyt}}$.

Effects of the bacterial compounds on $\left[\mathrm{Ca}^{2+}\right]_{\text {cyt }}$ concentration were monitored in cell suspensions of transgenic Nicotiana plumbaginifolia that constitutively expresses the $\mathrm{Ca}^{2+}$ reporter protein apoaequorin in the cytosol. All compounds ac-

Table 2. Medium alkalinization by tobacco cv. Xanthi cells in response to components of Pseudomonas putida WCS358, P. fluorescens WCS374, and P. fluorescens WCS417 and their mutants lacking the O-antigenic side-chain of the cell wall lipopolysaccharide $\left(\mathrm{OA}^{-}\right)$, the flagella $\left(\mathrm{FL}^{-}\right)$, or the pseudobactin siderophore $\left(\mathrm{PB}^{-}\right)^{\mathrm{a}}$

\begin{tabular}{|c|c|c|c|}
\hline \multirow[b]{2}{*}{$\begin{array}{l}\text { Bacterial } \\
\text { strain }\end{array}$} & \multicolumn{3}{|c|}{ Compound } \\
\hline & $\begin{array}{l}\text { Cell walls } \\
\left(10 \mu \mathrm{g} \mathrm{ml}^{-1}\right)\end{array}$ & $\begin{array}{c}\text { Flagella } \\
\left(1 \mu \mathrm{g} \mathrm{ml}^{-1}\right)\end{array}$ & $\begin{array}{c}\text { Pseudobactin } \\
\left(10 \mu \mathrm{g} \mathrm{ml}^{-1}\right)\end{array}$ \\
\hline \multicolumn{4}{|l|}{ WCS358 } \\
\hline WT & 1.11 & 1.15 & 0 \\
\hline $\mathrm{OA}^{-}$ & 1.21 & - & - \\
\hline $\mathrm{FL}^{-}$ & 1.23 & - & - \\
\hline $\mathrm{PB}^{-}$ & 0.50 & - & - \\
\hline \multicolumn{4}{|l|}{ WCS374 } \\
\hline WT & 0.90 & 0.98 & 1.00 \\
\hline $\mathrm{OA}^{-}$ & 0.92 & - & - \\
\hline $\mathrm{FL}^{-}$ & 1.16 & - & - \\
\hline $\mathrm{PB}^{-}$ & 0.96 & - & - \\
\hline \multicolumn{4}{|l|}{ WCS417 } \\
\hline WT & 0.91 & 0.47 & 0 \\
\hline $\mathrm{OA}^{-}$ & 0.88 & - & - \\
\hline $\mathrm{FL}^{-}$ & 1.24 & - & - \\
\hline $\mathrm{PB}^{-}$ & 1.01 & - & - \\
\hline
\end{tabular}

${ }^{\mathrm{a}}$ Maximum increases in $\mathrm{pH}(\Delta \mathrm{pH}$ units) reached by 10 to $20 \mathrm{~min}$ after addition of the compounds are indicated; WT $=$ wild type and $-=$ not determined. 
tive in inducing alkalinization in the tobacco cell culture provoked a similar transient increase in $\left[\mathrm{Ca}^{2+}\right]_{\text {cyt }}$ in the N. plumbaginifolia cells, as exemplified in Figure 8A for cell walls of WCS358. After a substantial peak at approximately $6 \mathrm{~min}$, $\left[\mathrm{Ca}^{2+}\right]_{\text {cyt }}$ declined quickly for $4 \mathrm{~min}$ and then more slowly for another $20 \mathrm{~min}$ until basal levels were again reached. Cell walls of the $\mathrm{FL}^{-}$mutant induced a lower response, whereas the cell walls of the $\mathrm{PB}^{-}$mutant, that were ineffective in inducing an oxidative burst (Table 1), induced a still lower response (Fig. 8A), comparable with their effect on medium alkalinization (Table 2). In contrast to the siderophore of WCS374 (Fig. 8B), the siderophores of WCS358 and WCS417, that were not active in medium alkalinization, induced an identical, relatively strong peak during the first $2 \mathrm{~min}$ followed by an only minor elevation at approximately $6 \mathrm{~min}$ (Fig. 8A, shown for PB 358 only). This indicates that these siderophores did affect the tobacco cells, be it only briefly and apparently without provoking further responses.

Cryptogein provoked an increase in $\left[\mathrm{Ca}^{2+}\right]_{\text {cyt }}$ comparable with the rhizobacterial cell walls but peaking slightly later (Fig. 8B). Compared with cell walls of wild-type WCS417, those from its $\mathrm{OA}^{-}$mutant with reduced activity in eliciting active oxygen species (Table 1) and medium alkalinization (Table 2) were largely inactive. In contrast, flagella that did not induce an oxidative
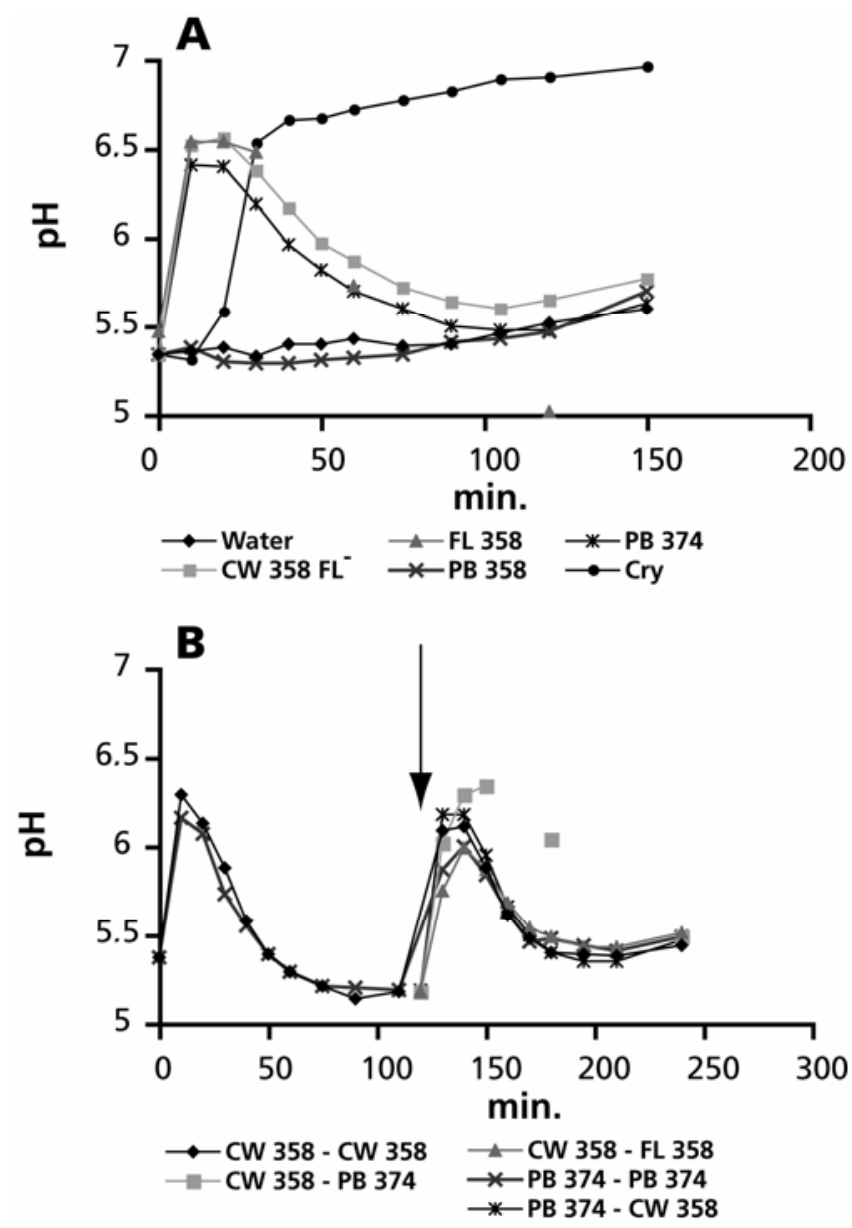

Fig. 6. Medium alkalinization by tobacco cv. Xanthi suspension cells upon addition of rhizobacterial elicitors $\left(10 \mu \mathrm{g} \mathrm{ml}^{-1}\right)$ or cryptogein $(25 \mathrm{nM})$. A, Water control $(\diamond)$, cell walls from the flagella-minus $\left(\mathrm{FL}^{-}\right)$mutant of Pseudomonas putida WCS358 (ロ), FL 358 (ム), PB 358 (×), PB 374 (*), or cryptogein $(\bullet)$. B, CW 358 followed at $120 \mathrm{~min}$ (arrow) by re-addition of CW $358(\diamond)$, by addition of PB 374 at 120 min ( $)$ or addition of FL 358 at $120 \mathrm{~min}(\mathbf{\Delta})$, PB 374 followed by re-addition of PB 374 at $120 \mathrm{~min}$ $(\times)$ or addition of $\mathrm{CW} 358$ at $120 \mathrm{~min}(\boldsymbol{*})$. The data are from representative experiments out of a total of eight. burst but were active in provoking medium alkalinization led to a $\mathrm{Ca}^{2+}$ influx comparable with that caused by the cell wall preparations of the three strains or the siderophore of WCS374, as shown for the flagella of WCS374 (Fig. 8B).

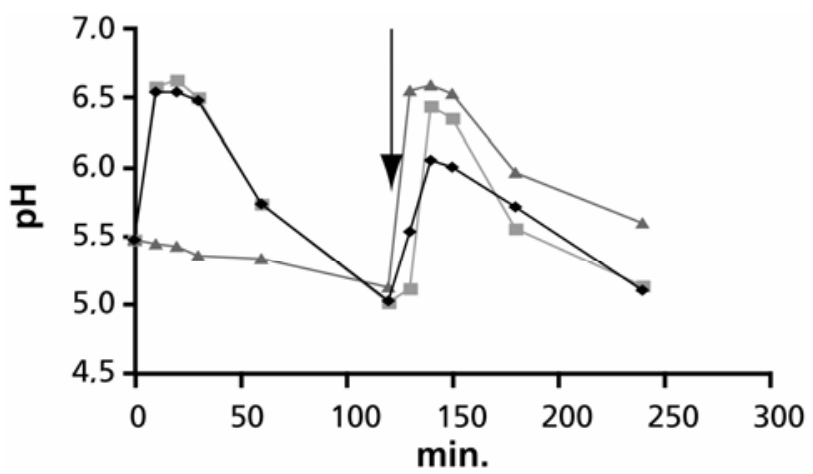

$\multimap$ FL 358 - FL $358-$ FL 358 - CW $358 \mathrm{FL}^{-} \longrightarrow$-Water- CW $358 \mathrm{FL}^{-}$

Fig. 7. Medium alkalinization by tobacco cv. Xanthi suspension cells upon addition of flagella of Pseudomonas putida WCS358 prior to or following the crude cell walls: FL 358 followed at $120 \mathrm{~min}$ (arrow) by re-addition of FL $358(\diamond)$, FL 358 followed by cell walls from the flagella-minus $\left(\mathrm{FL}^{-}\right)$ mutant of WCS358 at $120 \mathrm{~min}(\mathbf{\square})$, or addition of cell walls from the $\mathrm{FL}^{-}$ mutant at $120 \mathrm{~min}$ to a water control $(\boldsymbol{\Delta})$. The data are from representative experiments out of a total of four.
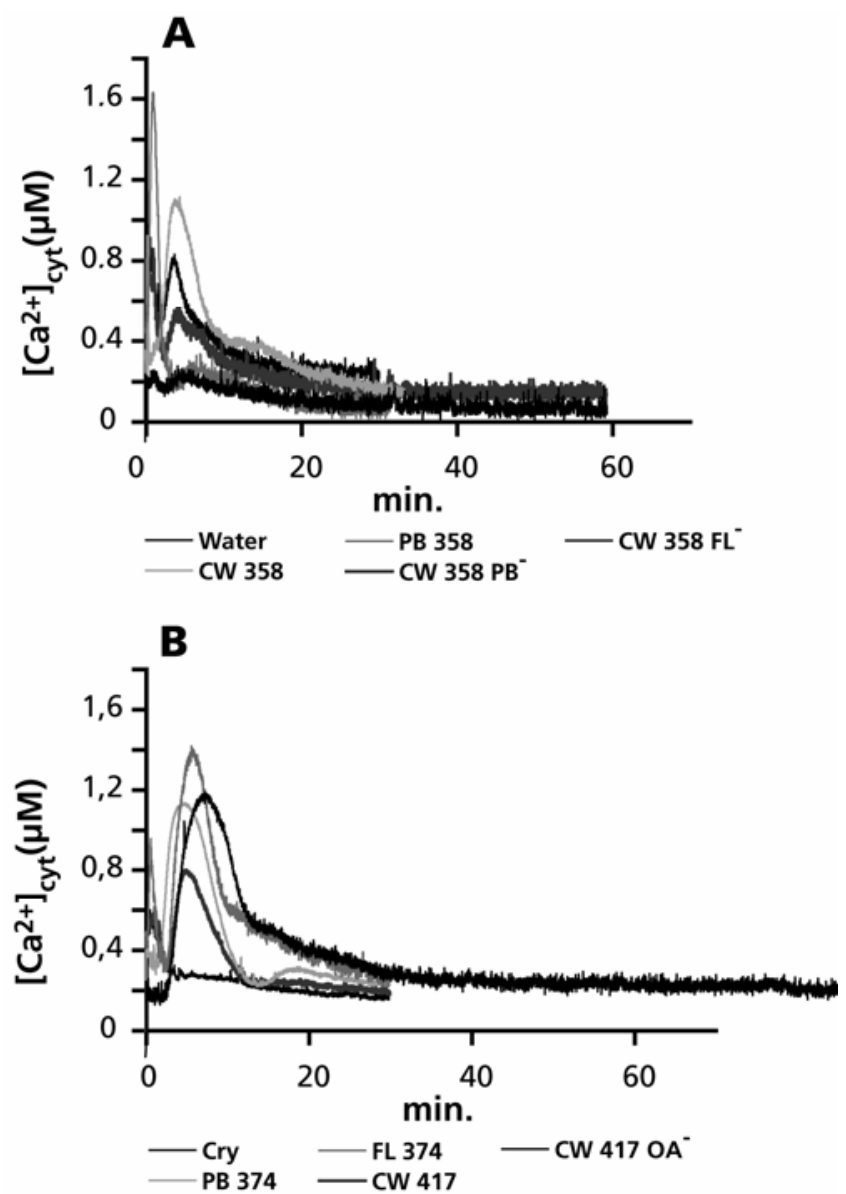

Fig. 8. Changes in cytoplasmic $\mathrm{Ca}^{2+}\left(\left[\mathrm{Ca}^{2+}\right]_{\text {cyt }}\right)$ in suspension cells of aequorin-containing transgenic Nicotiana plumbaginifolia upon addition of A, water, CW $358\left(100 \mu \mathrm{g} \mathrm{ml}^{-1}\right)$, PB $358\left(100 \mu \mathrm{g} \mathrm{ml}^{-1}\right)$, and cell walls from the siderophore-minus $\left(\mathrm{PB}^{-}\right)$or flagella-minus $\left(\mathrm{FL}^{-)}\right.$mutants of $P$. putida WCS358 $\left(100 \mu \mathrm{g} \mathrm{ml}^{-1}\right)$; and $\mathbf{B}$, cryptogein $(1 \mu \mathrm{M})$, PB $374(100 \mu \mathrm{g}$ $\left.\mathrm{ml}^{-1}\right)$, FL $374\left(20 \mu \mathrm{g} \mathrm{ml}^{-1}\right)$, CW $417\left(100 \mu \mathrm{g} \mathrm{ml}^{-1}\right)$, or cell walls from the $\mathrm{OA}^{-}$mutant of $P$. fluorescens WCS417 $\left(100 \mu \mathrm{g} \mathrm{ml}^{-1}\right)$. The data are from representative experiments out of a total of six. 
Expression of defense-related genes.

To determine whether elicitor-active LPS or siderophore induced expression of defense-related genes, activation in response to cell walls of WCS358 or the siderophore of WCS374 was studied by Northern blotting (Fig. 9). Several genes showed a weak, transient induction starting before $1 \mathrm{~h}$ after elicitation. In all cases, induction subsided after $12 \mathrm{~h}$. Upon elicitation by the cell walls, maximum expression of $P A L$ and GST was evident after $3 \mathrm{~h}$, whereas $P R-3$ and $A C O$ showed maximum levels already after $1 \mathrm{~h}$. In response to the siderophore, expression of PAL, LOX, and GST peaked at $6 \mathrm{~h}$ and expression of $P R-3$ and $A C O$ appeared negligible. Thus, elicitation of the tobacco cells by the rhizobacterial compounds led to rather similar, weak, transient expression of a number of defense-related genes.

\section{Induction of systemic resistance.}

To be able to relate the observed early effects on tobacco suspension cells to induction of systemic resistance in whole plants, bioassays were conducted in which the roots of tobacco seedlings were dipped in suspensions of live bacteria or the eliciting compounds and plants were challenged 2 weeks later with either the bacterial soft rot pathogen E. carotovora or Tobacco mosaic virus (TMV). Live WCS358 bacteria significantly reduced bacterial soft rot, whereas WCS374 and WCS417 did not (Fig. 10A). The resistance-inducing activity of WCS358 was lost in the $\mathrm{PB}^{-}$and the $\mathrm{FL}^{-}$mutants but retained in the $\mathrm{OA}^{-}$mutant (Fig. 10B; $\mathrm{FL}^{-}$not shown). In contrast to the wild type and the $\mathrm{OA}^{-}$and $\mathrm{PB}^{-}$mutants, which colonized the tobacco roots to levels of at least $10^{6} \mathrm{CFU} / \mathrm{g}$ root, the $\mathrm{FL}^{-}$mutant was impaired in root colonization. For this reason, the inability of the $\mathrm{FL}^{-}$mutant to induce systemic resistance may be due to its inability to reach a sufficiently high population density on the roots.

Based on the inability of the $\mathrm{PB}^{-}$mutant to induce systemic resistance, the pseudobactin siderophore of WCS358 can be implicated as a resistance-inducing determinant. Indeed, treatment with the purified pseudobactin triggered ISR, as did the cell wall preparation, to the same extent as live cells (Fig. 11). Although live cells of WCS374 and WCS417 did not trigger ISR (Fig. 10), their pseudobactins as well as their cell walls did induce a systemic protective effect against E. carotovora (Fig. 11). These results suggest that either the compounds produced in vitro on plate media are structurally different from those produced in vivo in the rhizosphere or, in the rhizosphere, the active structures of these components are not exposed to the root cells.

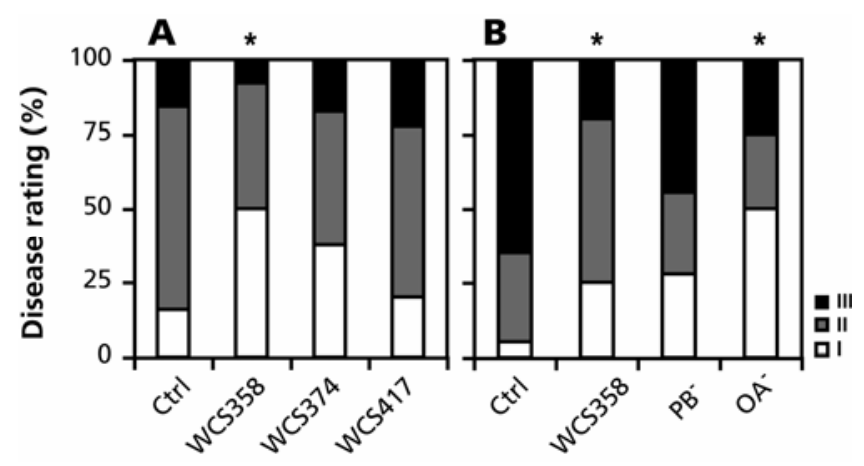

Fig. 10. Induction of systemic resistance against Erwinia carotovora in tobacco cv. Samsun NN plants treated with $0.1 \mathrm{mM} \mathrm{MgSO}_{4}(\mathrm{Ctrl})$ or suspensions containing $5 \times 10^{8} \mathrm{CFU}$ of live A, wild-type Pseudomonas putida WCS358, P. fluorescens WCS374, or P. fluorescens WCS417; and B, wild-type $P$. putida WCS358 and its mutants lacking the O-antigenic side chain of the cell wall lipopolysaccharide $\left(\mathrm{OA}^{-}\right)$or the pseudobactin siderophore $\left(\mathrm{PB}^{-}\right)$. Soft rot lesion sizes were determined 3 days after inoculation and disease ratings were expressed as percentages of lesions in classes I (no lesion expansion), II (lesion expansion up to $5 \mathrm{~mm}$ ), and III (lesion expansion $>5 \mathrm{~mm}$ ). Asterisks indicate statistically significantly different distributions of the disease-severity classes compared with the noninduced control treatments $\left(\chi^{2}, \alpha=0.05\right)$ from a total of 12 experiments.

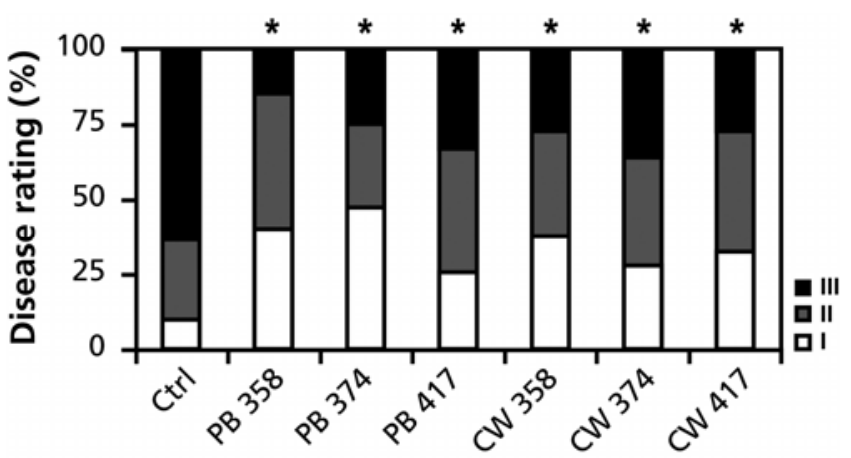

Fig. 11. Induction of systemic resistance against Erwinia carotovora in tobacco cv. Samsun NN plants treated with $0.1 \mathrm{mM} \mathrm{MgSO}_{4}(\mathrm{Ctrl})$ and either cell walls (CW) or purified pseudobactin (PB) (both at $10 \mu \mathrm{g} \mathrm{ml}^{-1}$ ) of Pseudomonas putida WCS358, P. fluorescens WCS374, or $P$. fluorescens WCS417. Soft rot lesion sizes were determined 3 days after inoculation and disease ratings were expressed as percentages of lesions in classes I (no lesion expansion), II (lesion expansion up to $5 \mathrm{~mm}$ ), and III (lesion expansion $>5 \mathrm{~mm}$ ). Asterisks indicate statistically significantly different distributions of the disease-severity classes compared with the noninduced control treatments $\left(\chi^{2}, \alpha=0.05\right)$. The data are representative of three experiments.

CW 358

PB 374

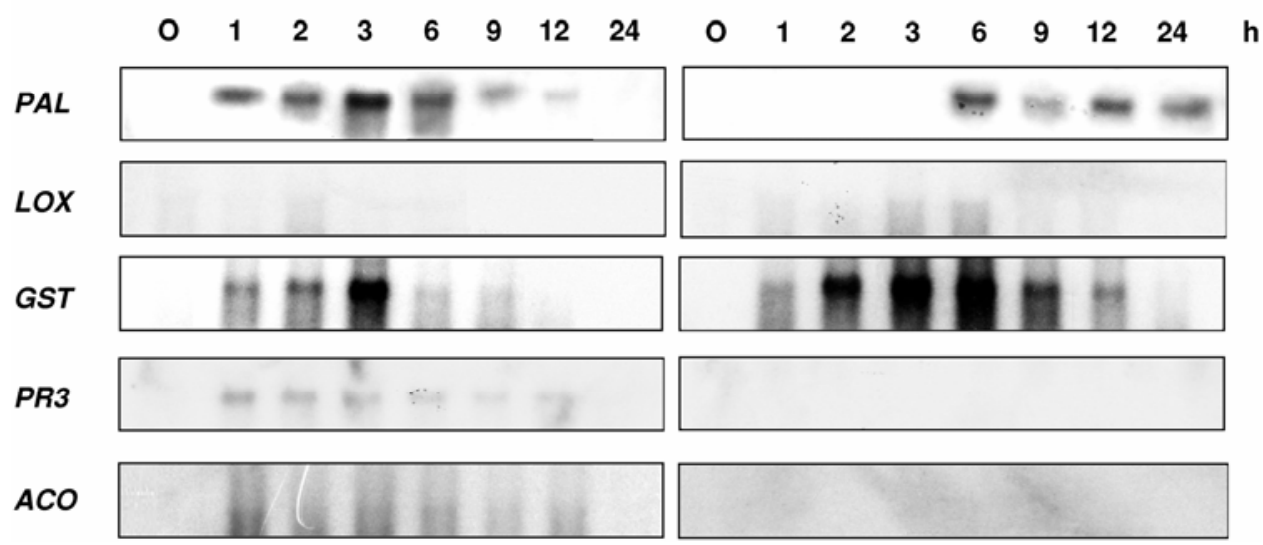

Fig. 9. Expression of defense-related genes $P A L$ (encoding phenylalanine ammonia-lyase), LOX (lipoxygenase), GST (glutathion S-transferase), $P R$-3 (patho-

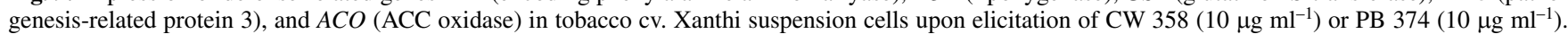
The data are representative of three experiments. 
None of the bacterial strains induced systemic resistance to TMV (data not shown), confirming and extending previous results that WCS417-mediated ISR is not effective against viruses (Ton et al. 2002).

\section{DISCUSSION}

Production of AOS, medium alkalinization, and $\left[\mathrm{Ca}^{2+}\right]$ influx are common reactions of plant suspension cells to biotic stresses. Notably, AOS have been associated with stress adaptation as well as programmed cell death (Gechev et al. 2006), and are known to act as signals mediating both defense gene activation and the execution of the hypersensitive reaction in response to pathogens (Torres et al. 2006). In tobacco cell suspensions, the reactions to the elicitor cryptogein have been well characterized (Garcia-Brugger et al. 2006), involving not only an oxidative burst, rise in extracellular $\mathrm{pH}$, cytosol acidification, and $\left[\mathrm{Ca}^{2+}\right]$ influx but also a rapid efflux of nitrate anions, generation of NO, activation of protein kinases, defenserelated gene expression, and, finally, cell death. These reactions appear typical of microbial effectors triggering reactions that lead to a hypersensitive response.

The elicitors from nonpathogenic rhizobacteria that induce systemic resistance prime plants for enhanced defense reactions upon challenge inoculation with a pathogen but are characteristically not associated with extensive transcriptional reprogramming or with cell death (Van Loon 2007; Verhagen et al. 2004). Unlike cryptogein, which triggered a rapid and longlasting production of AOS by the tobacco suspension cells, cell wall preparations of the rhizobacterial strains WCS358, WCS374, and WCS417; the pseudobactin siderophore of WCS374; and flagella of WCS358 all induced a rapid, but transient, oxidative burst lasting less than $30 \mathrm{~min}$, similar to the one induced by the active flagellar peptide flg22. Whereas treatment with cryptogein led to cell death, cells treated with the rhizobacterial elicitors remained fully viable for at least 24 h. Their oxidative burst was also similar to the ones induced by the $\beta$-1,3-glucan laminarin in tobacco (Ménard et al. 2004) and grapevine cells (Aziz et al. 2003), which were demonstrated to be associated with increased defense-related gene expression and induced resistance in intact plants against $E$. carotovora, and Botrytis cinerea and Plasmopara viticola, respectively. Because cell walls of the $\mathrm{FL}^{-}$mutants of the rhizobacterial strains WCS358, WCS374, and WCS417 were as active as those from the wild types, flagella were not required for the induction of the oxidative burst. In addition to flagella, the cell wall preparations consisted of the membranous LPS, which was shown earlier to be an inducing determinant of ISR in several plant species, including radish (Van Loon 2007). At least in radish, induction of systemic resistance requires a minimum population density of the rhizobacteria of $10^{5} \mathrm{CFU} / \mathrm{g}$ of root and reaches a maximum at approximately $10^{6} \mathrm{CFU} \mathrm{g}^{-1}$ (Raaijmakers et al. 1995). Based on the yield of the bacterial compounds obtained during preparation, these numbers fit very well with the observed dose-response curve for the oxidative burst, with a threshold for cell walls at $1 \mu \mathrm{g} \mathrm{m}^{-1}$ corresponding to $10^{5}$ $\mathrm{CFU}$ and the response leveling off above $10 \mu \mathrm{g} \mathrm{ml}^{-1}$. Hence, it is most likely the LPS that is responsible for the induction of the oxidative burst.

The cell wall LPS of gram-negative bacteria consists of a lipid A moiety, a conserved core oligosaccharide, and a highly variable $\mathrm{O}$-antigenic carbohydrate side chain. The detailed structures of the LPS of strains WCS358, WCS374, and WCS417 are not known; however, the observations that cell walls of $\mathrm{OA}^{-}$mutants of WCS358 and WCS374 that lacked the $\mathrm{O}$-antigenic side chain were as active as those from the corresponding wild types suggest that, for these strains, the lipid A and core oligosaccharide are sufficient to trigger a full oxidative burst. This was not the case for the $\mathrm{OA}^{-}$mutant of WCS417, which showed only one-third of the activity of wildtype cell walls. Thus, for WCS417, the O-antigenic side chain seems largely responsible. So far, receptors for bacterial LPS have not been identified in plants (Newman et al. 2007). How different structures can lead to an apparently identical oxidative burst remains to be established.

The ability to trigger a similar oxidative burst seems to be more common among rhizobacterial LPS, as shown for Burkholderia cepacia (Gerber et al. 2004). Perception of the LPS of this strain likewise triggered a rapid rise in extracellular $\mathrm{pH}, \mathrm{Ca}^{2+}$ influx (Gerber et al. 2004), defense-related gene expression, and, in intact plants, protection against Phytophthora nicotianae (Coventry and Dubery 2001). In contrast, LPS of the pathogenic bacterium $X$. campestris pv. campestris triggered an oxidative burst that started later and was prolonged (Meyer et al. 2001), resembling more the reaction to cryptogein. In common with the reaction of cryptogein-treated tobacco cells, the reaction to the rhizobacterial LPS-containing cell walls was blocked by EGTA, $\mathrm{LaCl}_{3}$, staurosporine, and DPI, indicating that the oxidative burst is commonly dependent on $\mathrm{Ca}^{2+}$ influx and protein phosphorylation, and involves the plasma-membrane-bound NADPH oxidase.

A second stimulation of the tobacco cells by addition of one of the active bacterial compounds after the initial oxidative burst had passed showed that, in all combinations, a state of either complete or at least substantial refractoriness was evident. In contrast, addition of cryptogein after bacterial compounds led to a full cryptogein-specific production of AOS, demonstrating that the cells had retained their full capacity to develop an oxidative burst. Hence, the refractoriness to the rhizobacterial compounds must be due to a desensitization as a result of the initial burst. The fact that the cell walls of the three strains as well as the siderophore of WCS374 and the flagella of WCS358 all induced, and were sensitive to, this desensitization strongly suggests that the same signaling pathway, or common signaling components involved in the regulation of the oxidative burst, were activated. However, it is highly unlikely that the structurally divergent compounds were all recognized by the same receptor. The small second bursts seen when flagella were employed prior to or after treatment with cell walls, when cell walls of WCS417 were added after cell walls of WCS374 and, notably, when cell walls followed treatment with the pseudobactin of WCS374, indicate that quantitative variations occurred that were more pronounced as the bacterial components were more dissimilar. Hence, it is most likely that signaling upon perception by different receptors converges rapidly into a common response pathway.

Extracellular medium alkalinization was induced with identical kinetics, involving a rise of more than one $\mathrm{pH}$ unit within 10 min, by the cell walls of the three rhizobacterial strains and the siderophore of WCS374 but not the pseudobactins of WCS358 or WCS417. A short, transient depolarization measured on roots of intact radish plants 10 min after dipping in a suspension of live cells of WCS374 (H. Steijl and A. van Bel, unpublished) indicates that a kinetically similar response is evident in intact roots. Medium alkalinization is the common parameter employed to monitor the action of the bacterial PAMP flagellin (Felix et al. 1999). Our observations agree with this notion, in that the flagella of not only WCS358 but also WCS374 and, to a slightly lesser extent, WCS417 led to a rise in extracellular $\mathrm{pH}$. However, our observations that the flagella of WCS374 and WCS417 did not induce any significant oxidative burst in the tobacco cells indicate that the production of AOS and medium alkalinization are not necessarily correlated. As is evident from the use of the inhibitors, medium alkalinization was independent 
of the action of the $\mathrm{H}_{2} \mathrm{O}_{2}$-producing NADPH oxidase, although it did require protein phosphorylation and $\mathrm{Ca}^{2+}$ influx. Moreover, stimulated cells became hardly refractory to medium alkalinization upon repeated stimulation.

From the literature, it is evident that the kinetics of changes in extracellular $\mathrm{pH}$ are different for elicitors that induce a comparable oxidative burst. The alkalinization of the medium of tobacco cells upon treatment with the LPS from $B$. cepacia was much smaller and was maintained for at least $60 \mathrm{~min}$ (Gerber et al. 2004), whereas the reaction to laminarin was completely terminated by $30 \mathrm{~min}$ (Klarzynski et al. 2000). Moreover, $\left[\mathrm{Ca}^{2+}\right]_{\text {cyt }}$ increased only slowly in aequorin-transformed tobacco cells treated with LPS from B. cepacia (Gerber et al. 2004). In contrast, the increase in response to the cell walls of WCS358, WCS374, and WCS417; the siderophore of WCS374; and flagella of the three strains was much more rapid and transient, proving rather similar to the one induced by applying flg22 (Lecourieux et al. 2005) or LPS of pathogenic X. campestris pv. campestris bacteria (Meyer et al. 2001) and dissimilar from the one induced by laminarin (Lecourieux et al. 2006). The siderophores of WCS358 and WCS417 were perceived by the tobacco cells, as evidenced by the strong spike of $\left[\mathrm{Ca}^{2+}\right]_{\text {cyt }} 1 \mathrm{~min}$ after their addition. This response was very different from the one induced by the other rhizobacterial compounds. These results demonstrate that these compounds induced partly similar, partly different responses in the tobacco suspension cells compared with published data on other bacterially derived elicitors. Such differences may be related to the use of different cell lines varying in their reactions and sensitivities to similar compounds. Moreover, during signaling, different responses can result from differences in the timing and the intensity of similar responses.

Treatment of tobacco suspension cells with laminarin or LPS from B. cepacia was shown to result in an accumulation of PR proteins (Coventry and Dubery 2001; Klarzynski et al. 2003) and an induction in intact plants of systemic resistance against $E$. carotovora and $P$. nicotianae, respectively. Similarly, infiltration of leaves on Arabidopsis plants with flg22 or LPS preparations from the nonpathogenic bacteria Escherichia coli and Pseudomonas aeruginosa increased SA levels and induced $P R$ gene expression, as well as both local and systemic acquired resistance against $P$. syringae pv. maculicola (Mishina and Zeier 2007), similar to the flg22-triggered ISR against $P$. syringae pv. tomato (Zipfel et al. 2004). In contrast, WCS417 ISR-elicited in Arabidopsis against several pathogens (Ton et al. 2002) and insects (Van Oosten et al. 2008 ) is associated neither with increases in SA, JA, or ethylene (Pieterse et al. 2000), nor with $P R$-gene expression in the leaves (Verhagen et al. 2004). In the tobacco suspension cells, at least the cell walls of WCS358 and the siderophore of WCS374 induced a transient expression of a range of defense-related genes over the first $24 \mathrm{~h}$, including SA-inducible $P R-3$, JA-regulated $L O X$, and ethylene-stimulated $A C O$. Apparently, the active rhizobacterial elicitors stimulate defense-related gene expression only temporarily at an early stage, and this may or may not reflect the primed state that results from the induction of ISR.

Induction of systemic resistance was tested by challenging treated plants with either the bacterial pathogen Erwinia carotovora or the virus TMV. E. carotovora has been shown to be sensitive to SA-independent but ethylene-dependent defenses (Geraats et al. 2003; Vidal et al. 1998) and, therefore, should be sensitive to the JA- and ethylene-dependent ISR induced by the large majority of nonpathogenic rhizobacteria (Ton et al. 2002; Van Loon and Bakker 2005). In contrast, TMV is resisted by SA-dependent defenses and sensitive to SAR (Ryals et al. 1996). In agreement with these different characteristics, none of the bacterial treatments induced resistance against TMV, whereas ISR against $E$. carotovora was induced by one of the three bacterial strains and by all of the purified cell wall and siderophore preparations.

The expression of ISR against E. carotovora in treated plants did not correlate with the reactions of the tobacco suspension cells to the rhizobacterial compounds. Whereas, in the cell suspensions, the cell wall LPS of WCS358, WCS374, and WCS417 and the siderophore of WCS374 all induced the production of AOS, medium alkalinization and an increase in $\left[\mathrm{Ca}^{2+}\right]_{\text {cyt }}$, in whole plants, live bacteria of only strain WCS358 triggered significant ISR. Its cell wall LPS and pseudobactin siderophore were similarly active, in spite of the fact that the latter did not provoke an oxidative burst or a rise in extracellular $\mathrm{pH}$ in the cell suspension. In accordance with these results, the $\mathrm{OA}^{-}$mutant could still trigger ISR through its siderophore, whereas the $\mathrm{PB}^{-}$mutant appeared to be impaired in its cell-wall-dependent activity also: its cell walls did not induce an oxidative burst in the suspension-cultured cells. Apparently, the $\mathrm{PB}^{-}$mutant had lost both its LPS and siderophore activity to elicit ISR. The results obtained with WCS374 and WCS417 are more difficult to interpret. In spite of the absence of ISR elicited by live cells of these two strains, their cell wall LPS and siderophores were all active in eliciting ISR against $E$. carotovora. This discrepancy may be explained by differences in the structure or the expression of these determinants between bacteria grown under different conditions (Newman et al. 2007).

These results clearly demonstrate that the ability of a rhizobacterial elicitor to trigger early signaling events commonly related to defense responses in tobacco suspension cells does not necessarily correspond to its resistance-inducing properties in intact tobacco plants. Suspension cells differ physiologically from cells in intact plant tissues, and the chlorophyll-containing tobacco cells used do not visibly resemble the chlorophyll-lacking root cells that must be the site of perception of the bacterial compounds in vivo. Additionally, the reactions measured in suspension cells are local reactions, whereas ISR is a systemic response that must be mediated by distinct signaling compounds that are generated locally and transported throughout the plant. Verhagen and associates (2004) showed that, in Arabidopsis, strain WCS417 induced distinct changes in gene expression locally in the roots but only primed the leaves for defense without any obvious alterations in gene expression-which occur merely after challenge inoculation. Similarly, sulfated laminarin elicited an oxidative burst and $P R$-gene expression in tobacco but protected against TMV only locally, not systemically (Ménard et al. 2004, 2005).

The poor correlation between the defense-related reactions in suspension-cultured cells and the elicitation of ISR in whole plants indicates that the relationship between early reactions, such as the production of AOS, the extracellular alkalinization, and the signature of the $\mathrm{Ca}^{2+}$ signal, is not straightforward, and that their interpretation needs caution as well as further consideration. The parameters are obviously useful in analyzing the perception and early signal transduction of rhizobacterial compounds. However, their relationship to the generation and establishment of ISR remains far from clear.

\section{MATERIALS AND METHODS}

\section{Cultivation of bacteria and preparation} of bacterial components and cryptogein.

Bacterial strains and mutants are listed in Table 3. P. putida WCS358, P. fluorescens WCS374, and P. fluorescens WCS417 and their mutants were grown for $24 \mathrm{~h}$ on King's medium B 
(KB) agar plates (King et al. 1954) at $28^{\circ} \mathrm{C}$. The cells were collected in $10 \mathrm{mM} \mathrm{MgSO}_{4}$, washed twice by centrifugation for 5 min at 5,000 $\times g$, and finally resuspended in $10 \mathrm{mM} \mathrm{MgSO}_{4}$.

All bacterial compounds were prepared at least twice from batches cultured at different times. Lipopolysaccharide-containing cell walls (crude LPS) were isolated essentially as described previously (Leeman et al. 1995). Bacterial cells were resuspended in $10 \mathrm{mM}$ phosphate-buffered saline (PBS), $\mathrm{pH}$ 7.2. The suspension was centrifuged for $10 \mathrm{~min}$ at $8,000 \times g$, and the pellet washed again and lyophilized. Lyophilized cells $(100 \mathrm{mg}$ ) were resuspended in $10 \mathrm{ml}$ of $50 \mathrm{mM}$ Tris- $\mathrm{HCl}, 2$ mM EDTA, pH 8.5, and sonicated 20 times at resonance amplitude for $15 \mathrm{~s}$ at 0 to $4^{\circ} \mathrm{C}$. The translucent sonicated suspension was centrifuged for $20 \mathrm{~min}$ at $600 \times g$ to remove intact cells, and the supernatant was centrifuged again for $60 \mathrm{~min}$ at $8,000 \times g$ to obtain the broken cell walls as a pellet. The pellet was lyophilized and the dry powder was stored at 0 to $4^{\circ} \mathrm{C}$.

For the preparation of flagella, bacterial cells were resuspended in $20 \mathrm{mM} \mathrm{K}$-phosphate buffer, $\mathrm{pH} 7.4$, washed by centrifugation, and treated in a blender (Ultra-Turrex T25, Janke \& Kunkel IKA Labortechnic) at 21,000 rpm to shear off the flagella. Intact cells and cell debris were removed by centrifugation for $1 \mathrm{~h}$ at $23,400 \times g$ at $4^{\circ} \mathrm{C}$. The supernatant was centrifuged for $4 \mathrm{~h}$ at $60,000 \times g$ at $4^{\circ} \mathrm{C}$ to obtain the flagella as a pellet. The pellet was lyophilized and stored at $-20^{\circ} \mathrm{C}$.

Purified pseudobactin siderophores were isolated from culture supernatants of bacteria grown for 4 days in 2 liters of standard succinate medium, $\mathrm{pH} 7$, at $28^{\circ} \mathrm{C}$. Cells were removed by centrifugation for $20 \mathrm{~min}$ at $5,700 \times g$, the supernatant was lyophilized in darkness, and the pseudobactin was purified as described by Raaijmakers and associates (1994). After chromatography, using PD10 columns (Pharmacia), the pseudobactin-containing fractions were collected, lyophilized, and stored as a dry powder in darkness at 0 to $4^{\circ} \mathrm{C}$. Purity was checked based on the molar extinction coefficient of 13,670 at $400 \mathrm{~nm}$ and $\mathrm{pH} 7$ of pseudobactin 358 and by analytical high-performance liquid chromatography using purified pseudobactin 374 as a reference (Djavaheri 2007).

For testing, all preparations were suspended in sterile distilled water to a concentration of $1 \mathrm{mg} \mathrm{ml}-1$. To saturate pseudobactin preparations with iron, solutions were brought to $0.9 \mathrm{mM} \mathrm{FeCl}_{3}$ (approximately $110 \% \mathrm{Fe}$ ). The addition of Fe to the siderophore preparations had no significant effect on the production of AOS. Furthermore, none of the preparations possessed any catalase activity as measured by a change in absorbance at $240 \mathrm{~nm}$ upon addition of $\mathrm{H}_{2} \mathrm{O}_{2}$, ruling out quenching in the determination of AOS-eliciting activity.

The pathogen $E$. carotovora pv. carotovora was grown for 24 $\mathrm{h}$ in liquid Luria-Bertani (LB) medium (Miller 1972) at $28^{\circ} \mathrm{C}$.
Cells were collected by centrifugation and the supernatant recentrifuged for $20 \mathrm{~min}$ at $8,000 \times g$. The pellets were resuspended in $10 \mathrm{mM} \mathrm{MgSO}_{4}$, whereas the supernatant was filtered through a $0.2-\mu \mathrm{m}$ polycarbonate filter and the filtrate checked for the absence of bacterial cells by plating on LB agar plates. A $50 \%$ dilution of the cell-free supernatant was used as a source of auto-inducers to stimulate the virulence of the pathogen on tobacco (Smadja et al. 2004).

Cryptogein was purified according to Bonnet and associates (1996) and dissolved in water as a 100- $\mu \mathrm{M}$ stock solution.

\section{Plant material.}

Cell suspensions of tobacco (N. tabacum cv. Xanthi) and transgenic aequorin-expressing $N$. plumbaginifolia were grown as described previously (Lecourieux et al. 2002; Pugin et al. 1997) and subcultured weekly. Cells were maintained in the exponential phase of growth and subcultured 1 day prior to utilization.

Tobacco plants (cv. Samsun NN) were grown from seed in a greenhouse under controlled conditions (Geraats et al. 2003) for 6 to 8 weeks. After inoculation with the pathogen, plants were kept under a glass cover to maintain relative humidity near $100 \%$.

\section{Chemicals.}

All chemicals were of analytical grade and purchased from Sigma-Aldrich (Saint-Quentin-Fallavier, France). The chemicals were dissolved in water except for staurosporine, which was prepared as a stock solution in dimethyl sulfoxide.

\section{Determination of AOS.}

The production of AOS by the cells was assayed by chemiluminescence, using luminol as reagent (Pugin et al. 1997). Briefly, cells were washed by filtration and resuspended to 0.1 $\mathrm{g}$ fresh weight $\mathrm{ml}^{-1}$ in buffer (10 mM HEPES, $175 \mathrm{mM}$ mannitol, $\left.0.5 \mathrm{mM} \mathrm{CaCl}_{2}, 0.5 \mathrm{mM} \mathrm{K}_{2} \mathrm{SO}_{4}, \mathrm{pH} 5.75\right)$, and then equilibrated for $2 \mathrm{~h}$ at $24^{\circ} \mathrm{C}$ on a rotary shaker $(150 \mathrm{rpm})$ before treatments. Typically, $3 \times 10^{5}$ cells are present per $0.1 \mathrm{~g}$ fresh weight in the suspensions. Upon addition of test compounds, samples of $250 \mu \mathrm{l}$ were withdrawn every $5 \mathrm{~min}$ and added to $350 \mu \mathrm{l}$ of $50 \mathrm{mM}$ HEPES, $175 \mathrm{mM}$ mannitol, $0.5 \mathrm{mM} \mathrm{CaCl}_{2}$, $0.5 \mathrm{mM} \mathrm{K}_{2} \mathrm{SO}_{4}, \mathrm{pH} 6.5$, and luminol (final concentration 25 $\mu \mathrm{M})$. Chemiluminescence was measured using a luminometer (Lumat LB9507, Berthold, Bad Wildbad, Germany) for $10 \mathrm{~s}$ and expressed in nanomoles of $\mathrm{H}_{2} \mathrm{O}_{2}$ per gram fresh weight of cells, based on a standard calibration curve obtained by $\mathrm{H}_{2} \mathrm{O}_{2}$ addition to tobacco cell suspension aliquots.

Inhibitors were added 5 min before the addition of the test compounds.

Table 3. Bacterial strains and mutants used in this study

\begin{tabular}{|c|c|c|}
\hline Strain & Origin and relevant properties & Reference \\
\hline Erwinia carotovora pv. carotovora SCC3193 & Isolated from infected potato & Pirhonen et al. 1988 \\
\hline Pseudomonas fluorescens WCS374 & Isolated from potato rhizosphere & Geels and Schippers 1983 \\
\hline P. fluorescens WCS374r & Spontaneous rifampicin-resistant derivative of WCS374 & Geels and Schippers 1983 \\
\hline WCS374 LWP74 30b & Spontaneous O-antigen-negative mutant of WCS374 & De Weger et al. 1989 \\
\hline WCS374 L29 & WCS374 Tn5 mutant lacking flagella & De Weger et al. 1987 \\
\hline WCS374 Mut2 & WCS374 Tn5 mutant lacking pseudobactin & Weisbeek et al. 1986 \\
\hline P. fluorescens WCS417 & Isolated from wheat rhizosphere & Lamers et al. 1988 \\
\hline P. fluorescens WCS417r & Spontaneous rifampicin-resistant derivative of WCS417 & Van Peer et al. 1990 \\
\hline WCS417 UP17 B4 & Spontaneous O-antigen-negative mutant of WCS417 & Leeman et al. 1996 \\
\hline WCS417 Mob-10 & WCS417 Tn5 mutant lacking flagella & P. A. H. M. Bakker, unpublished \\
\hline WCS417 S680 & WCS417 Tn5 mutant lacking pseudobactin & Duijff et al. 1993 \\
\hline P. putida WCS358 & Isolated from potato rhizosphere & Geels and Schippers 1983 \\
\hline P. putida WCS358r & Spontaneous rifampicin-resistant derivative of WCS358 & Glandorf et al. 1992 \\
\hline WCS358 43B & Spontaneous O-antigen-negative mutant of WCS358 & De Weger et al. 1987 \\
\hline WCS358 GMB6 & WCS358 Tn5 mutant lacking flagella & L. A. de Weger, unpublished \\
\hline WCS358 JM218 & WCS358 Tn5 mutant lacking pseudobactin & Marugg et al. 1985 \\
\hline
\end{tabular}


Determination of medium $\mathbf{p H}$.

Extracellular $\mathrm{pH}$ was measured with a glass combination electrode every $10 \mathrm{~min}$ on pre-equilibrated 1 -g aliquots of cells in $2 \mathrm{mM}$ HEPES, $0.5 \mathrm{mM} \mathrm{CaCl}_{2}, 0.5 \mathrm{mM} \mathrm{K}_{2} \mathrm{SO}_{4}, 175 \mathrm{mM}$ mannitol, pH 5.75.

\section{Measurements of $\left[\mathrm{Ca}^{2+}\right]_{\text {cyt }}$.}

Aequorin-expressing $N$. plumbaginifolia cells were suspended in $2 \mathrm{mM}$ HEPES, $0.5 \mathrm{mM} \mathrm{CaCl}, 0.5 \mathrm{mM} \mathrm{K}_{2} \mathrm{SO}_{4}, 175 \mathrm{mM}$ mannitol, $\mathrm{pH}$ 5.75. In vivo reconstitution of aequorin was performed by addition of $1 \mu \mathrm{M}$ coelenterazine to cells in suspension buffer for at least $3 \mathrm{~h}$ in the dark $\left(150 \mathrm{rpm}, 24^{\circ} \mathrm{C}\right)$. Coelenterazine is a prosthetic group of aequorin required for its full $\mathrm{Ca}^{2+}$-binding activity. The bioluminescence of $250-\mu \mathrm{l}$ aliquots of cells (maintained in a cuvette) was recorded continuously at 1-s intervals by digital luminometry. At the end of the experiments, residual functional aequorin was quantified by adding $300 \mu \mathrm{l}$ of lysis buffer $\left(10 \mathrm{mM} \mathrm{CaCl}_{2}, 2 \%\right.$ Nonidet P40 [vol/vol], $10 \%$ ethanol [vol/vol]) and monitoring the resulting increase in luminescence. Luminescence data transformation into cytosolic $\mathrm{Ca}^{2+}$ concentration was performed as described previously (Lecourieux et al. 2002).

\section{Monitoring of cell death.}

Cell viability was assayed using the vital dye Neutral Red as described by Binet and associates (2001). To $2 \mathrm{ml}$ of cell suspension in $10 \mathrm{mM}$ HEPES, $0.5 \mathrm{mM} \mathrm{CaCl}_{2}, 0.5 \mathrm{mM} \mathrm{K}_{2} \mathrm{SO}_{4}$, $175 \mathrm{mM}$ mannitol, pH 5.75, the test compound, and $20 \mu \mathrm{l}$ of $1 \%$ Neutral Red solution were added and the cells were incubated on a rotary shaker at room temperature. Dead cells that had not accumulated the dye were counted $24 \mathrm{~h}$ later.

\section{Determination of defense-related gene expression.}

Upon addition of LPS-containing cell walls of strain WCS358 or the pseudobactin siderophore of WCS374 to the tobacco cell suspension maintained in the culture medium, 2.5$\mathrm{ml}$ samples were withdrawn at intervals, filtered, and immediately frozen. Total RNA was extracted using Trizol reagent (Gibco BRL, Gaithersburg, MD, U.S.A.) according to the supplier's instructions. Total RNA (10 $\mu \mathrm{g}$ per lane) was separated on $1.2 \%$ agarose gels $(\mathrm{wt} / \mathrm{vol})$ containing $1.1 \%$ formaldehyde (wt/vol), blotted to a nylon membrane (Hybond-XL; Amersham Biosciences, Piscataway, NJ, U.S.A.), and cross-linked by UV light. The cDNA clones used as probes for hybridization were labeled by random priming (Ready-To-Go DNA Labelling Beads -dCTP; Amersham Biosciences). Membrane hybridization was performed at $65^{\circ} \mathrm{C}$ as described by Church and Gilbert (1984). The membrane was washed with $2 \times$ SSC (1× $\mathrm{SSC}$ is $0.15 \mathrm{M} \mathrm{NaCl}, 0.015 \mathrm{M}$ sodium citrate, $\mathrm{pH}$ 7) twice for $5 \mathrm{~min}$ at room temperature, with $0.5 \%$ sodium dodecyl sulfate (wt/vol) and $2 \times \mathrm{SSC}$ twice for $30 \mathrm{~min}$ at $65^{\circ} \mathrm{C}$, and subsequently with $0.1 \% \mathrm{SSC}$ twice for $30 \mathrm{~min}$ at room temperature. The membrane was then exposed to X-Omat AR film (Kodak, Rochester, NY, U.S.A.).

\section{Bioassay for ISR.}

Four-week-old tobacco seedlings were uprooted and treated by dipping the root system in a $200-\mathrm{ml}$ suspension of live bacteria $\left(10^{8} \mathrm{CFU} / \mathrm{ml}\right)$ or bacterial component $\left(25 \mu \mathrm{g} \mathrm{ml}^{-1}\right)$ in 10 $\mathrm{mM} \mathrm{MgSO}_{4}$ for $15 \mathrm{~s}$ before transplanting into a sand-potting soil mixture that had been autoclaved twice with a 24 -h interval. After 14 days, the plants were challenge inoculated with E. carotovora by infiltrating three leaves with 50 to $75 \mu \mathrm{l}$ of a suspension of the pathogen $\left(10^{8} \mathrm{CFU} \mathrm{ml^{-1 }}\right.$ in $50 \%$ cell-free culture filtrate), using a syringe without a needle, and kept for 3 days at $100 \%$ relative humidity. During this period, soft rot lesion development was monitored daily. Lesion sizes were de- termined after 3 days, and disease ratings were expressed as percentages of lesions in classes I (no lesion expansion), II (lesion expansion up to $5 \mathrm{~mm}$ ), and III (lesion expansion $>5 \mathrm{~mm}$ ). Data were analyzed statistically by SPSS version $14.0\left(\chi^{2}, \alpha=\right.$ $0.05)$.

Alternatively, plants were challenged by inoculation with purified TMV and lesion sizes were determined 7 days later, as described previously (Knoester et al. 2001).

\section{Root colonization by Pseudomonas strains.}

To determine the ability of the three rhizobacterial strains to colonize tobacco roots to high levels, rifampicin-resistant derivatives of strains WCS358, WCS374, and WCS417 were employed. Rhizosphere population densities were determined 1 week after transplanting and treatment of the roots with $10^{8}$ $\mathrm{CFU} \mathrm{ml} \mathrm{m}^{-1}$. The roots of two plants per treatment were harvested, weighed, rinsed briefly in water, and shaken vigorously for 1 min in glass tubes containing $5 \mathrm{ml}$ of $10 \mathrm{mM} \mathrm{MgSO}_{4}$ and $0.5 \mathrm{~g}$ of glass beads $(0.17 \mathrm{~mm})$. Appropriate dilutions were plated on $\mathrm{KB}$ agar supplemented with cycloheximide (100 mg liter ${ }^{-1}$ ), ampicillin $\left(40 \mathrm{mg} \mathrm{liter}^{-1}\right)$, chloramphenicol $\left(13 \mathrm{mg} \mathrm{liter}^{-1}\right)$, and rifampicin $\left(150 \mathrm{mg} \mathrm{liter}^{-1}\right)$. After overnight incubation at $28^{\circ} \mathrm{C}$, the number of CFU per gram of root fresh weight was determined.

All experiments were conducted at least twice with similar results. All data reported are from representative experiments. Variation within experiments was negligible; variation between experiments was due entirely to minor differences in responsiveness between individual batches of tobacco suspension cells.

\section{ACKNOWLEDGMENTS}

We thank A. Chiltz for maintaining the tobacco suspension cultures, $\mathrm{O}$ Lamotte for help in calculating $\left[\mathrm{Ca}^{2+}\right]_{\text {cyt }}$ levels, O. van Zwienen and $\mathrm{M}$. Dijkhuijsen for performing the bioassays with TMV, and T. Boller for a gift of flg22.

\section{LITERATURE CITED}

Asai, T., Tena, G., Plotnikova, J., Willmann, M. R., Chiu, W.-L., GomezGomez, L., Boller, T., Ausubel, F. M., and Sheen, J. 2002. MAP kinase signalling cascade in Arabidopsis innate immunity. Nature 415:977-983.

Aziz, A., Poinssot, B., Daire, X., Adrian, M., Bézier, A., Lambert, B., Joubert, J.-M., and Pugin, A. 2003. Laminarin elicits defense responses in grapevine and induces protection against Botrytis cinerea and Plasmopara viticola. Mol. Plant-Microbe Interact. 16:1118-1128.

Bakker, P. A. H. M., Pieterse, C. M. J., and Van Loon, L. C. 2007. Induced systemic resistance by fluorescent Pseudomonas spp. Phytopathology 97:239-243.

Bellingham, N. F., Morgan, J. A. W., Saunders, J. R., and Winstanley, C. 2001. Flagellin gene sequence variation in the genus Pseudomonas. Syst. Appl. Microbiol. 24:157-165.

Binet, M. N., Humbert, C., Lecourieux, D., Vantard, M., and Pugin, A. 2001. Disruption of microtubular cytoskeleton induced by cryptogein, an elicitor of hypersensitive response in tobacco cells. Plant Physiol. 125:564-584.

Bonnet, P., Bourdon, E., Ponchet, M., Blein, J. P., and Ricci, P. 1996. Acquired resistance triggered by elicitins in tobacco and other plants. Eur. J. Plant Pathol. 102:181-192.

Church, G. M., and Gilbert, W. 1984. Genomic sequencing. Proc. Natl. Acad. Sci. U.S.A. 81:1991-1995

Coventry, H. S., and Dubery, I. A. 2001. Lipopolysaccharides from Burkholderia cepacia contribute to an enhanced defensive capacity and the induction of pathogenesis-related proteins in Nicotianae tabacum. Physiol. Mol. Plant Pathol. 58:149-158.

Desender, S., Andrivon, D., and Val, F. 2007. Activation of defence reactions in Solanaceae: Where is the specificity? Cell. Microbiol. 9:21-30.

De Weger, L. A., Jann, B., Kann, K., and Lugtenberg, B. 1987. Lipopolysaccharides of Pseudomonas spp. that stimulate plant growth: Composition and use for strain identification. J. Bacteriol. 169:1441-1446.

De Weger, L. A., Van Loosdrecht, C. M., Klaassen, H. E., and Lugtenberg, B. 1989. Mutational changes in physicochemical cell surface properties of plant-growth-stimulating Pseudomonas spp. do not influence the attachment properties of the cells. J. Bacteriol. 171:2756-2761. 
Djavaheri, M. 2007. Iron-regulated metabolites of plant growth promoting Pseudomonas fluorescens WCS374: Their role in induced systemic resistance. Ph.D. thesis, Utrecht University, Utrecht, The Netherlands.

Duijff, B. J., Meijer, J. M., Bakker, P. A. H. M., and Schippers, B. 1993. Siderophore-mediated competition for iron and induced resistance in the suppression of fusarium wilt of carnation by fluorescent Pseudomonas spp. Neth. J. Plant Pathol. 99:277-289.

Erbs, G., and Newman, M. A. 2003. The role of lipopolysaccharides in induction of plant defence responses. Mol. Plant Pathol. 4:421-425.

Felix, G., Duran, J. D., Volko, S., and Boller, T. 1999. Plants have a sensitive perception system for the most conserved domain of bacterial flagellin. Plant J. 18:265-276.

Fett, J. P., LeVier, K., and Guerinot, M. L. 1998. Soil microorganisms and iron uptake by higher plants. Metal Ions Biol. Syst. 35:187-214.

Garcia-Brugger, A., Lamotte, O., Vandelle, E., Bourque, S., Lecourieux, D., Poinssot, B., Wendehenne, D., and Pugin, A. 2006. Early signaling events induced by elicitors of plant defenses. Mol. Plant-Microbe Interact. 19:711-724

Gechev, T. S., Van Breusegem, F., Stone, J. M., Denev, I., and Laloi, C. 2006. Reactive oxygen species as signals that modulate plant stress responses and programmed cell death. BioEssays 28:1091-1101.

Geels, F. P., and Schippers, B. 1983. Selection of antagonistic fluorescent Pseudomonas spp. and their root colonization and persistence following treatment of seed potatoes. Phytopathol. Z. 108:193-206.

Geraats, B. P. J., Bakker, P. A. H. M., Lawrence, C. B., Achuo, E. A. Höfte, M., and Van Loon, L. C. 2003. Ethylene-insensitive tobacco shows differentially altered susceptibility to different pathogens. Phytopathology 93:813-821.

Gerber, I. B., and Dubery, I. A. 2004. Protein phosphorylation in Nicotiana tabacum cells in response to perception of lipopolysaccharides from Burkholderia cepacia. Phytochemistry 65:2957-2966.

Gerber, I. B., Zeidler, D., Durner, J., and Dubery, I. A. 2004. Early perception responses of Nicotiana tabacum cells in response to lipopolysaccharides from Burkholderia cepacia. Planta 218:647-657.

Gerber, I. B., Laukens, K., Witters, E., and Dubery, I. A. 2006. Lipopolysaccharide-responsive phosphoproteins in Nicotiana tabacum cells. Plant Physiol. Biochem. 44:369-379.

Glandorf, D. C. M., Brand, I., Bakker, P. A. H. M., and Schippers, B. 1992. Stability of rifampicin resistance as a marker for root colonization studies of Pseudomonas putida in the field. Plant Soil 147:135-142.

Gómez-Gómez, L., Felix, G., and Boller, T. 1999. A single locus determines sensitivity to bacterial flagellin in Arabidopsis thaliana. Plant J. $18: 277-284$

Gómez-Gómez, L., Bauer, Z., and Boller, T. 2001. Both the extracellular leucine-rich repeat domain and the kinase activity of FLS2 are required for flagellin binding and signaling in Arabidopsis. Plant Cell 13:11551163.

Graham, T. L., Sequeira, L., and Huang, T.-S. R. 1977. Bacterial lipopolysaccharides as inducers of disease resistance in tobacco. Appl. Environ. Microbiol. 34:424-432.

Handelsman, J., and Stabb, E. V. 1996. Biocontrol of soilborne plant pathogens. Plant Cell 8:1855-1869.

He, P., Shan, L., and Sheen, J. 2007. Elicitation and suppression of microbeassociated molecular pattern-triggered immunity in plant-microbe interactions. Cell. Microbiol. 9:1385-1396.

Höfte, M. 1993. Classes of microbial siderophores. Pages 3-26 in: Iron Chelation in Plants and Soil Microorganisms. L. L. Barton and B. C. Hemming, eds. Academic Press, San Diego, CA, U.S.A.

Jones, J. D. G., and Dangl, J. L. 2006. The plant immune system. Nature 444:323-329.

King, E. O., Ward, M. K., and Raney, D. E. 1954. Two simple media for the demonstration of phycocyanin and fluorescin. J. Lab. Clin. Med. 44:301-307.

Klarzynski, O., Plesse, B., Joubert, J.-M., Yvin, J.-C., Kopp, M., Kloareg, B., and Fritig, B. 2000. Linear $\beta-1,3$ glucans are elicitors of defense responses in tobacco. Plant Physiol. 124:1027-1037.

Klarzynski, O., Descamps, V., Plesse, B., Yvin, J.-C., Kloareg, B., and Fritig, B. 2003. Sulfated fucan oligosaccharides elicit defense responses in tobacco and local and systemic resistance against tobacco mosaic virus. Mol. Plant-Microbe Interact. 16:115-122.

Knoester, M., Linthorst, H. J. M., Bol, J. F., and Van Loon, L. C. 2001. Involvement of ethylene in lesion development and systemic acquired resistance in tobacco during the hypersensitive reaction to tobacco mosaic virus. Physiol. Mol. Plant Pathol. 59:45-57.

Lamers, J. G., Schippers, B., and Geels, F. P. 1988. Soil-borne disease of wheat in the Netherlands and results of seed bacterization with pseudomonads against Gaeumannomyces graminis var. tritici, associated with disease resistance. Pages 134-139 in: Cereal Breeding Related to Integrated Cereal Production. M. L. Jorna and L. A. J. Slootmaker, eds. Pudoc, Wageningen, The Netherlands.
Lecourieux, D., Mazars, C., Pauly, N., Ranjeva, R., and Pugin, A. 2002 Analysis and effects of cytosolic free calcium increases in response to elicitors in Nicotiana plumbaginifolia cells. Plant Cell 14:2627-2641.

Lecourieux, D., Lamotte, O., Bourque, S., Wendehenne, D., Mazars, C., Ranjeva, R., and Pugin, A. 2005. Proteinaceous and oligosaccharidic elicitors induce different calcium signatures in the nucleus of tobacco cells. Cell Calcium 38:527-538.

Lecourieux, D., Ranjeva, R., and Pugin, A. 2006. Calcium in plant defence-signalling pathways. New Phytol. 171:249-269.

Leeman, M., Van Pelt, J. A., Den Ouden, F. M., Heinsbroek, M., Bakker, P. A. H. M., and Schippers, B. 1995. Induction of systemic resistance against Fusarium wilt of radish by lipopolysaccharides of Pseudomonas fluorescens. Phytopathology 85:1021-1027.

Leeman, M., Den Ouden, F. M., Van Pelt, J. A., Dirkx, F. P. M., Steijl, H., Bakker, P. A. H. M., and Schippers, B. 1996. Iron availability affects induction of systemic resistance against Fusarium wilt of radish by Pseudomonas fluorescens. Phytopathology 86:149-155.

Lerouge, I., and Vanderleyden, J. 2001. O-antigen structural variation: Mechanisms and possible roles in animal/plant-microbe interactions. FEMS (Fed. Eur. Microbiol. Soc.) Microbiol. Rev. 26:17-47.

Li, X., Lin, H., Zhang, W., Zou, Y., Zhang, J., Tang, X., and Zhou, J.-M. 2005. Flagellin induces innate immunity in nonhost interactions that is suppressed by Pseudomonas syringae effectors. Proc. Natl. Acad. Sci. U.S.A. 102:12990-12995.

Lugtenberg, B. J. J., Dekkers, L., and Bloemberg, G. V. 2001. Molecular determinants of rhizosphere colonization by Pseudomonas. Annu. Rey. Phytopathol. 39:461-490.

Marugg, J. D., Van Spanje, M., Hoekstra, W. P. M., Schippers, B., and Weisbeek, P. J. 1985. Isolation and analysis of genes involved in siderophore biosynthesis in plant growth stimulating Pseudomonas putida WCS358. J. Bacteriol. 164:563-570.

Maurhofer, M., Hase, C., Meuwly, P., Métraux, J.-P., and Défago, G. 1994 Induction of systemic resistance of tobacco to tobacco necrosis virus by the root-colonizing Pseudomonas fluorescens strain CHA0: Influence of the gacA gene and of pyoverdine production. Phytopathology 84:139-146.

Ménard, R., Alban, S., De Ruffray, P., Jamois, F., Franz, G., Fritig, B. Yvin, J.-C., and Kauffmann, S. 2004. $\beta-1,3$ Glucan sulfate, but not $\beta$ 1,3 glucan, induces the salicylic acid signaling pathway in tobacco and Arabidopsis. Plant Cell 16:3020-3032.

Ménard, R., De Ruffray, P., Fritig, B., Yvin, J.-C., and Kauffmann, S. 2005. Defense and resistance-inducing activities in tobacco of the sulfated $\beta-1,3$ glucan PS3 and its synergistic activities with the unsulfated molecule. Plant Cell Physiol. 46:1964-1972.

Meyer, A., Pühler, A., and Niehaus, K. 2001. The lipopolysaccharides of the phytopathogen Xanthomonas campestris pv. campestris induce an oxidative burst reaction in cell cultures of Nicotiana tabacum. Planta 213:214-222.

Meziane, H., Van der Sluis, I., Van Loon, L. C., Höfte, M., and Bakker, P. A. H. M. 2005. Determinants of Pseudomonas putida WCS358 involved in inducing systemic resistance in plants. Mol. Plant Pathol. 6:177-185.

Miller, J. 1972. Experiments in Molecular Genetics. Cold Spring Harbor Laboratory, Cold Spring Harbor, NY, U.S.A.

Mishina, T. E., and Zeier, J. 2007. Pathogen-associated molecular pattern recognition rather than development of tissue necrosis contributes to bacterial induction of systemic acquired resistance in Arabidopsis. Plant J. 50:500-513.

Newman, M.-A., Dow, J. M., Molinaro, A., and Parrilli, M. 2007. Priming, induction and modulation of plant defence responses by bacterial lipopolysaccharides. J. Endotoxin Res. 13:69-84.

Nürnberger, T., and Lipka, V. 2005. Non-host resistance in plants: New insights into an old phenomenon. Mol. Plant Pathol. 6:335-345.

Nürnberger, T., Brunner, F., Kemmerling, B., and Piater, L. 2004. Innate immunity in plants and animals: Striking similarities and obvious differences. Immunol. Rev. 198:249-266.

Piater, L. A., Nürnberger, T., and Dubery, I. A. 2004. Identification of a lipopolysaccharide responsive erk-like MAP kinase in tobacco leaf tissue. Mol. Plant Pathol. 5:331-341.

Pieterse, C. M. J., Van Wees, S. C. M., Van Pelt, J. A., Knoester, M., Laan, R., Gerrits, H., Weisbeek, P. J., and Van Loon, L. C. 1998. A novel signaling pathway controlling induced systemic resistance in Arabidopsis. Plant Cell 10:1571-1580.

Pieterse, C. M. J., Van Pelt, J. A., Ton, J., Parchmann, S., Mueller, M. J. Buchala, A. J., Métraux, J.-P., and Van Loon, L. C. 2000. Rhizobacteriamediated induced systemic resistance (ISR) in Arabidopsis requires sensitivity to jasmonate and ethylene but is not accompanied by an increase in their production. Physiol. Mol. Plant Pathol. 57:123-134.

Pirhonen, M., Heino, P., Helander, I., Harju, P., and Palva, E. T. 1988. Bacteriophage T4 resistant mutants of the plant pathogen Erwinia carotovora. Microb. Pathogenesis 4:359-367. 
Pugin, A., Frachisse, J.-M., Tavernier, E., Bligny, R., Gout, E., Douce, R., and Guern, J. 1997. Early events induced by the elicitor cryptogein in tobacco cells: Involvement of a plasma membrane NADPH oxidase and activation of glycolysis and the pentose phosphate pathway. Plant Cell 9:2077-2091.

Raaijmakers, J. M., Bitter, W., Punte, H. L. M., Bakker, P. A. H. M. Weisbeek, P. J., and Schippers, B. 1994. Siderophore-receptor PupA as a marker to monitor wild-type Pseudomonas putida WCS358 in natural environments. Appl. Environ. Microbiol. 60:1184-1190.

Raaijmakers, J. M., Leeman, M., Van Oorschot, M. P. M., Van der Sluis, I., Schippers, B., and Bakker, P. A. H. M. 1995. Dose-response relationships in biological control of Fusarium wilt of radish by Pseudomonas spp. Phytopathology 85:1075-1081.

Ran, L. X., Li, Z. N., Wu, G. J., Van Loon, L. C., and Bakker, P. A. H. M. 2005. Induction of systemic resistance against bacterial wilt in Eucalyptus urophylla by fluorescent Pseudomonas spp. Eur. J. Plant Pathol. 113:59-70.

Robatzek, S., Bittel, P., Chincilla, D., Köchner, P., Felix, G., Shiu, S.-H., and Boller, T. 2007. Molecular identification and characterization of the tomato flagellin receptor LeFLS2, an orthologue of Arabidopsis FLS2 exhibiting characteristically different perception specificities. Plant Mol. Biol. 64:539-547.

Robin, A., Mougel, C., Siblot, S., Vansuyt, G., Mazurier, S., and Lemanceau, P. 2006. Effect of ferritin overexpression in tobacco on the structure of bacterial and pseudomonad communities associated with the roots. FEMS (Fed. Eur. Microbiol. Soc.) Microbiol. Ecol. 58:492-502.

Ryals, J. A., Neuenschwander, U. H., Willits, M. G., Molina, A., Steiner, H. Y., and Hunt, M. D. 1996. Systemic acquired resistance. Plant Cell 8:1809-1819.

Sanabria, N. M., and Dubery, I. A. 2006. Differential display profiling of the Nicotiana response to LPS reveals elements of plant basal resistance. Biochem. Biophys. Res. Commun. 344:1001-1007.

Smadja, B., Latour, X., Faure, D., Chevalier, S., Dessaux, Y., and Orange, N. 2004. Involvement of $\mathrm{N}$-acylhomoserine lactones throughout plant infection by Erwinia carotovora subsp. atroseptica (Pectobacterium atrosepticum). Mol. Plant-Microbe Interact. 17:1269-1278.

Taguchi, F., Shimizu, R., Nakajima, R., Toyoda, K., Shiraishi, T., and Ichinose, Y. 2003a. Differential effects of flagellins from Pseudomonas syringae pv. tabaci, tomato and glycinea on plant defense response. Plant Physiol. Biochem. 41:165-174.

Taguchi, F., Shimizu, R., Inagaki, Y., Toyoda, K., Shiraishi, T., and Ichinose, Y. 2003b. Post-translational modification of flagellin determines the specificity of HR induction. Plant Cell Physiol. 44:342-349.

Tavernier, E., Wendehenne, D., Blein, J.-P., and Pugin, A. 1995. Involvement of free calcium in action of cryptogein, a proteinaceous elicitor of hypersensitive reaction in tobacco cells. Plant Physiol. 109:1025-1031.

Ton, J., Van Pelt, J. A., Van Loon, L. C., and Pieterse, C. M. J. 2002. Dif- ferential effectiveness of salicylate-dependent and jasmonate/ethylenedependent induced resistance in Arabidopsis. Mol. Plant-Microbe Interact. 15:27-34.

Torres, M. A., Jones, J. D. G., and Dangl, J. L. 2006. Reactive oxygen species signaling in response to pathogens. Plant Physiol. 141:373-378.

Van Loon, L. C. 2007. Plant responses to plant growth-promoting rhizobacteria. Eur. J. Plant Pathol. 119:243-254.

Van Loon, L. C., and Bakker, P. A. H. M. 2005. Induced systemic resistance as a mechanism of disease suppression by rhizobacteria. Pages 39-66 in: PGPR: Biocontrol and Biofertilization. Z. A. Siddiqui, ed. Springer Science, Dordrecht, The Netherlands.

Van Oosten, V. R., Bodenhausen, N., Reymond, P., Van Pelt, J. A., Van Loon, L. C., Dicke, M., and Pieterse, C. M. J. 2008. Differential effectiveness of microbially induced resistance against herbivorous insects in Arabidopsis. Mol. Plant-Microbe Interact. 21:919-930.

Van Peer, R., Van Kuik, A. J., Rattink, H., and Schippers, B. 1990. Control of Fusarium wilt in carnation grown on rockwool by Pseudomonas sp. strain WCS417r and by Fe-EDDHA. Neth. J. Plant Pathol. 96:119-132.

Van Wees, S. C. M., Pieterse, C. M. J., Trijssenaar, A., Van't Westende, Y., Hartog, F., and Van Loon, L. C. 1997. Differential induction of systemic resistance in Arabidopsis by biocontrol bacteria. Mol. Plant-Microbe Interact. 10:716-724

Verhagen, B. W. M., Glazebrook, J., Zhu, T., Chang, H. S., Van Loon, L. C., and Pieterse, C. M. J. 2004. The transcriptome of rhizobacteriainduced systemic resistance in Arabidopsis. Mol. Plant-Microbe Interact. 17:895-908.

Vidal, S., Eriksson, A. R. B., Montesano, M., Denecke, J., and Palva, E. T. 1998. Cell wall-degrading enzymes from Erwinia carotovora cooperate in the salicylic acid-independent induction of a plant defense response. Mol. Plant-Microbe Interact. 11:23-32.

Visca, P., Imperi, F., and Lamont, I. L. 2007. Pyoverdine siderophores: From biogenesis to biosignificance. Trends Microbiol. 15:22-30.

Weisbeek, P. J., Van der Hofstad, G. A. J. M., Schippers, B., and Marugg, J. D. 1986. Genetic analysis of the iron-uptake system of two plant growthpromoting Pseudomonas strains. Pages 299-313 in: Iron, Siderophores, and Plant Diseases. T. R. Swinburne, ed. Plenum Press, New York.

Yang, R.-B., Mark, M. R., Gray, A., Huang, A., Xie, M. H., Zhang, M., Goddard, A., Wood, W. I., Gurney, A. L., and Godowski, P. J. 1998. Toll-like receptor-2 mediates lipopolysaccharide-induced cellular signalling. Nature 395:284-288.

Zeidler, D., Zähringer, U., Gerber, I., Dubery, I., Hartung, T., Bors, W., Hutzler, P., and Durner, J. 2004. Innate immunity in Arabidopsis thaliana: Lipopolysaccharides activate nitric oxide synthase (NOS) and induce defense genes. Proc. Natl. Acad. Sci. U.S.A. 101:15811-15816.

Zipfel, C., Robatzek, S., Navarro, L., Oakeley, E. J., Jones, J. D. G., Felix, G., and Boller, T. 2004. Bacterial disease resistance in Arabidopsis through flagellin perception. Nature 428:764-767. 